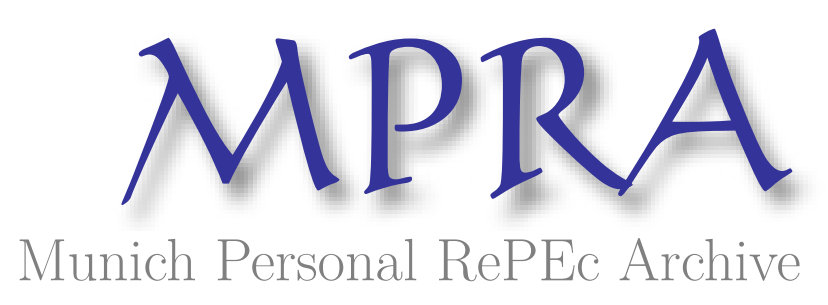

\title{
Evaluation of governance sustainability of Bulgarian agriculture
}

Bachev, Hrabrin

Institute of Agricultural Economics, Sofia

September 2020

Online at https://mpra.ub.uni-muenchen.de/103478/

MPRA Paper No. 103478, posted 16 Oct 2020 13:30 UTC 


\title{
Evaluation of Governance Sustainability of Bulgarian Agriculture
}

\author{
Hrabrin Bachev ${ }^{1}$
}

\author{
Institute of Agricultural Economics, Sofia
}

\begin{abstract}
A need to include "the fourth" Governance pillar in the concept for understanding and the assessment system of (overall and) agrarian sustainability is increasingly justified in academic literature and finds place in the frameworks of government, international, private, etc. organizations In Bulgaria, like in many other countries, practically there are no comprehensive assessments of the governance sustainability of agriculture and its importance for the overall agrarian development. This study tries to fill the gap and suggests a holistic framework for understanding and assessing the governance sustainability of Bulgarian agriculture. The newly elaborated approach is "tested" in a large-scale study for assessing the governance sustainability of country's agriculture at national, sectoral, regional, eco-system and farm levels.

The study has proved that it is important to include the "missing" Governance Pillar in the assessment of the Integral sustainability of agriculture and sustainability of agro-systems of various type. Multiple Principles, Criteria and Indicators assessment of the Governance sustainability of Bulgarian agriculture indicates that the Overall Governance Sustainability is at a "Good" but very close to the "Satisfactory" level. Besides, there is a considerable differentiation in the level of Integral Governance sustainability of different agro-systems in the country. What is more, the individual indicators with the highest and lowest sustainability values determine the "critical" factors enhancing and deterring the particular and integral Governance sustainability of evaluated agro-system. Last but not least important, results on the integral agrarian sustainability assessment based on micro (farm) and macro (statistical, etc.) data show some discrepancies which have to be taken into consideration in the analysis and interpretation, while assessment indicators, methods and data sources further improved.

Having in mind the importance of holistic assessments of this kind for improving the agrarian sustainability in general, and the Governance sustainability of agriculture in particular, they are to be expended and their precision and representation increased.
\end{abstract}

Key words: governance sustainability, assessment, agriculture, subsectors, agro-regions, agroecosystems, farming organizations, Bulgaria

\section{Introduction}

A common feature of all suggested and practically used modern systems for assessing sustainability of agro-systems is incorporation of three "dimensions" or "pillars" of sustainability - economic, social and environmental (Bachev et al, 2017; Cruz et al., 2018; EC, 2001; FAO, 2013; Hayati et al., 2010; Kamalia et al., 2017; Lopez-Ridauira et al., 2002; Lowrance et al., 2015; OECD, 2001; Sauvenier et al., 2005; Singh et al., 2009; Terziev et al. 2018; VanLoon et al., 2005). In the last years a special attention has been increasing put on the (good) "governance" as a key for achieving multiple goals of sustainable development at corporate, sectoral, national and international levels (Bachev, 2010; Bosselmann et. al., 2008; Gibson, 2006; EU, 2019; 
Simberova et al., 2012; Kayizari, 2018; UN. 2015). What is more, the list of sustainability objectives has been constantly enlarged encompassing numerous governance, cultural, ethical etc. standards and goals (Bachev, 2010; Scobie and Young 2018). Simultaneously "new" (cultural, human, governance, etc.) pillars has been widely added to the modern definition of sustainability and the systems of its evaluation and management (Altinay, 2012; ASA, 2019; Bachev, 2018; Nurse, 2006; RMIT University, 2017; UCLG, 2014).

The need to include "the fourth" governance pillar in the concept for understanding and the system of measurement of sustainability is increasingly justified in academic literature (Bachev, 2010, 2018; Baeker, 2014; Burford, 2017; Fraser et al., 2006; Monkelbaan, 2017) as well as finds place in the official documents of different (government, international, private, etc.) organizations (City of Brooks, 2019; EU, 2019; IFAD, 1999). Accordingly, numerous indicators are proposed to evaluate the governance aspect of sustainability mostly at national and international level including the state of formal institutional framework, implementing policies and strategies, human resources development, established capacity, management of public authorities, stakeholder involvement in public decision-making and control, etc. (Bell and Morse 2008; Bhuta and Umbach, 2014; CoastalWiki, 2019; Ganev et al.,2018; Monkelbaan, 2017; Spangenberg et al., 2002). Nevertheless, the building of the system for understating and assessing the "new" governance aspect (pillar) of agrarian sustainability is a "work in progress".

In Bulgaria, like in many other countries, there are a very few studies on governance issues related to agrarian sustainability (Bachev, 2010, 2018; Bachev et al., 2016; Bachev and Treziev, 2018; Georgiev, 2013; Marinov, 2019; Zvyatkova and Sarov, 2018) and the governance aspect (pillar) of agrarian sustainability (Bachev, 2016, 2017, 2018; Bachev et al. 2018; Bachev and Treziev, 2017, 2019). Moreover, practically there are no comprehensive assessments of the governance sustainability in the sector and its importance for the overall agrarian sustainability at present stage of development.

This paper tries to fill the gap and suggests a holistic framework for assessing the governance sustainability of Bulgarian agriculture. The newly elaborated approach is applied (tested) in a first in kind large-scale study for assessing the governance sustainability of country's agriculture at national, sectoral, regional, eco-system and farm levels, and its contribution to the overall agrarian sustainability in Bulgaria.

\section{Study Method and Data}

Sustainability of agriculture is a "system characteristic" and has to be perceived as "ability to continue over time" (Bachev, 2005; Hansen, 1996). It characterizes the ability (internal capability and adaptability) of agriculture to maintain its managerial, economic, social and environmental functions in a long period of time. Agrarian sustainability has four major aspects ("pillars") which are equally important and have to be always accounted for - governance sustainability, economic sustainability, social sustainability, and environmental sustainability.

The "governance sustainability" characterizes the efficiency of the specific system of governance in an evaluated agro-system (national, subsector, ecosystem, regional, farming enterprise, etc.). Accordingly, a "good governance" means a superior governance sustainability, while a "bad" (inefficient) governance corresponds to inferior governance sustainability.

Maintaining multiple functions (sustainability) of agriculture requires an effective social order - a system of diverse (governing) mechanisms and forms regulating, coordinating, stimulating, and controlling the behavior, actions and relations of individual agents at various 
levels - farm, local, regional, national, transnational, global (Bachev, 2010). The system of governance includes a number of district components all of which have to be included in the sustainability assessment - institutional environment ("rule of the game'), market modes and mechanisms ("'market order'), private modes and mechanisms ("private order'), and public modes and mechanisms ("public order') (Figure 1).

Figure 1. Components and Levels of Assessment of Governance Sustainability in Agriculture

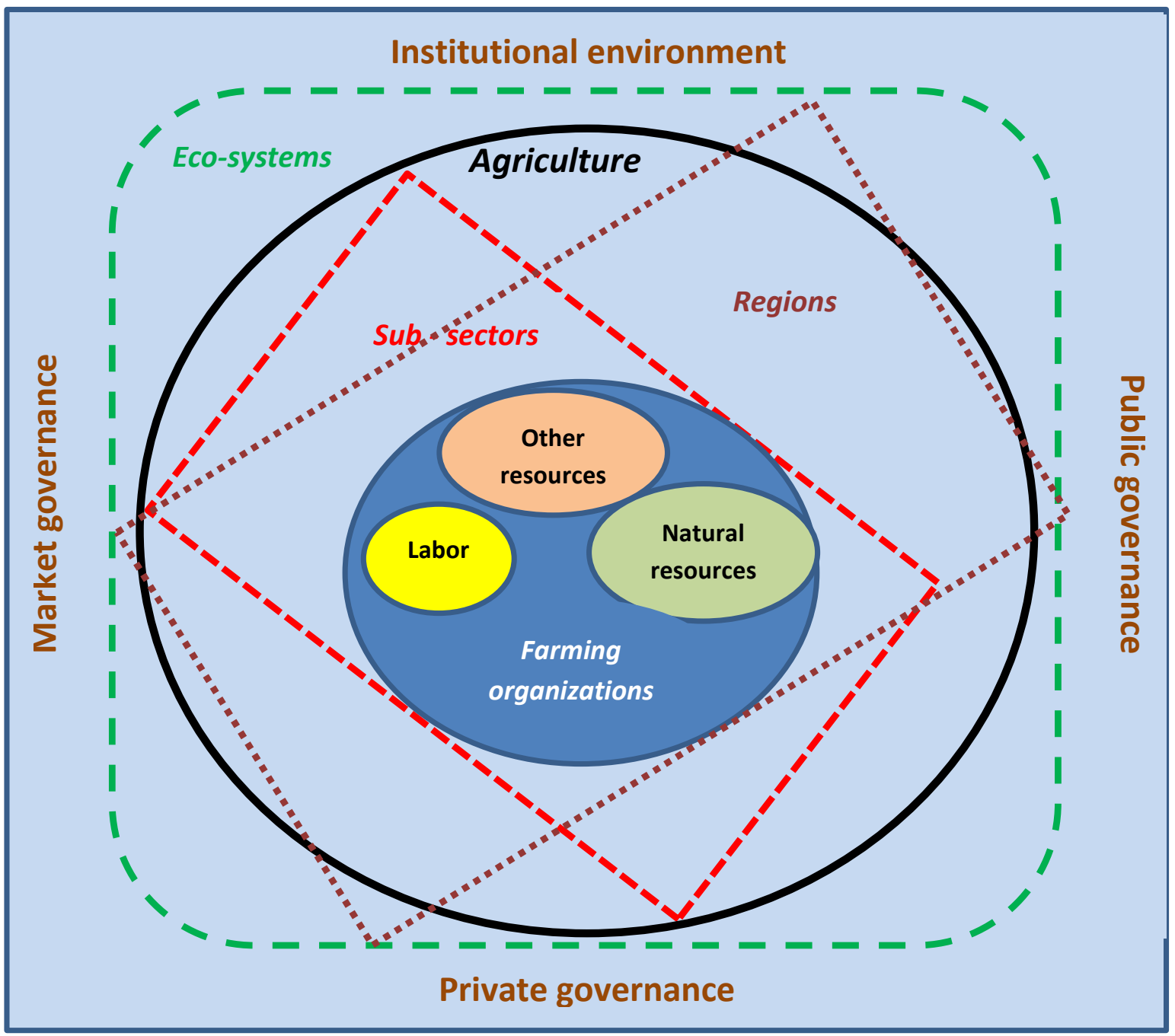

Source: author

Agriculture consists of many agro-systems - from individual "farming plot", a "farm enterprise", an "agri-ecosystem", an "agro-region", up to a "national", "European" and "global". In this study we focus on the assessment of the (governance) sustainability of Bulgarian agriculture at national level as well and for principle agricultural systems in the country - main type of farming organizations, major subsectors of agriculture, general kinds of agro-ecosystems, and all administrative (agro)regions (Figure 1). The farm is the lowest level, where the management and organization of agricultural activity (and sustainability) is carried out, and where all aspects of the agrarian sustainability are "realized" and could be feasibly assessed (Bachev, 2005). That is why the farm (agro-system) is the first level of agrarian (economic, governance, integral, etc.) sustainability assessment.

In order to identify the individual indicators for assessing the (governance) sustainability of Bulgarian agriculture a hierarchical system of well-determined Principles, Criteria, Indicators, and Reference Values for each Aspect (Pillar) of sustainability is elaborated. Detailed justification of that new approach, and the ways and criteria for selection of sustainability 
Principles, Criteria, Indicators and Reference Values are presented in other publications by Bachev (2017, 2018), and Bachev et al. (2017, 2018).

The Governance Sustainability Principles are "universal" and relate to the multiple functions of the agriculture representing the states of the sustainability, which is to be achieved (Figure 2). For the "specific" contemporary conditions of Bulgarian (and European Union) agriculture following five (governance sustainability) principles related to the generic (five) mechanisms and modes of governance ${ }^{2}$ are identified: "Good legislative system", "Democratic management", "Working agrarian administration", "Working market environment", and "Good private practices" (Table 1).

Figure 2. Framework for Assessing Sustainability of Bulgarian Agriculture



Source: author

The Governance Sustainability Criteria are precise standards ("measurement approaches") for each of the Principle representing a resulting state of the evaluated system when the relevant sustainability Principle is realized. For the contemporary conditions of the Bulgarian agriculture 20 Criteria for assessing diverse aspects of the governance sustainability are specified. For instance, for the Principle "Good legislative

${ }^{2}$ Components of the governance system of agriculture is comprehensively presented by Bachev (2010). 
system" four Criteria are selected: "Harmonization with the European Union policies", "Extent of the European Union policies implementation", "Beneficiaries' satisfaction of the European Union policies", and "Policies effects" (Table 1).

The Governance Sustainability Indicators are quantitative and qualitative variables of different types which can be assessed in the specific conditions of the evaluated agrisystem allowing measurement of compliance with a particular Criterion. The set of Indicators provides a representative picture for the agrarian sustainability in all its aspects. For assessing the Governance sustainability of the Bulgarian agriculture at micro (farm) and macro (sectoral, regional, eco-system, etc.) levels a system of respectively 22 and 26 Indicators are specified ${ }^{3}$. For instance, for the Criteria "Policies effects" an Indicator "Level of subsidies comparing to the average for the sector" is selected for farm level, as well as two Indicators for the aggregate (sectoral) level - "Coefficient of subsidies distribution from Pillar 1" and "Coefficient of distribution of investment support comparing to share in Net Value Added" (Table 1).

For assessing the particular sustainability level a system of specific Reference Values (sustainability norms, range, and standards) for each Indicator is needed. The Governance Sustainability Reference Values are the desirable levels for each Indicator according to the specific conditions of the evaluated agro-system. They assist the assessment of the sustainability levels giving guidance for achieving (maintaining, improving) particular aspect and the overall agrarian sustainability. Most of the Reference Values show the level(s), at which the long-term sustainability of agrarian Governance sustainability is "guaranteed" and improved. Depending on the extent of the Reference value achievement the evaluated agro-system may be with a "high", "good", or "low" sustainability, or to be "unsustainable". For instance, agrarian system with a higher than the sectoral public support (level of subsidies) is more sustainable then others as far as "Policy effects" are concerned, and vice versa.

\footnotetext{
${ }^{3}$ For the selection of the Sustainability Indicators a number of criteria, broadly applied in the sustainability assessment literature and practices, were used: "Relevance to reflecting aspects of sustainability", "Discriminatory power in time and space", "Analytical soundness", "Intelligibility and synonymity", "Measurability", "Governance and policy relevance", and "Practical applicability" (Sauvenier et al., 2005).
} 
Table 1. System of Principles, Criteria, Indicators, and Reference Values for Assessing Governance Sustainability of Bulgarian Agriculture

\begin{tabular}{|c|c|c|c|c|c|}
\hline \multirow{2}{*}{ Principles } & \multirow{2}{*}{ Criteria } & \multicolumn{2}{|c|}{ Indicators } & \multicolumn{2}{|c|}{ Reference values } \\
\hline & & Sectoral level & Farm level & Sectoral level & Farm level \\
\hline \multirow[t]{6}{*}{$\begin{array}{l}\text { Good } \\
\text { legislative } \\
\text { system }\end{array}$} & $\begin{array}{l}\text { Harmonizati } \\
\text { on with EU } \\
\text { policies }\end{array}$ & $\begin{array}{l}\text { Extent of policies } \\
\text { harmonization }\end{array}$ & na & Experts estimate & \\
\hline & \multirow[t]{2}{*}{$\begin{array}{l}\text { Extent of EU } \\
\text { policies } \\
\text { implementati } \\
\text { on }\end{array}$} & $\begin{array}{l}\text { Extent of financial } \\
\text { implementation of } \\
\text { policies }\end{array}$ & \multirow{2}{*}{$\begin{array}{l}\text { Extent of } \\
\text { CAP } \\
\text { implementati } \\
\text { on }\end{array}$} & Experts estimate & \multirow[t]{2}{*}{$\begin{array}{l}\text { Beneficiaries } \\
\text { estimates }\end{array}$} \\
\hline & & $\begin{array}{l}\text { Extent of } \\
\text { achievements of } \\
\text { objectives indicators }\end{array}$ & & Experts estimate & \\
\hline & $\begin{array}{l}\text { Beneficiaries } \\
\text { satisfaction } \\
\text { of EU } \\
\text { policies }\end{array}$ & $\begin{array}{l}\text { Extent of beneficiary } \\
\text { satisfaction of EU } \\
\text { policies }\end{array}$ & $\begin{array}{l}\text { Extent of } \\
\text { beneficiary } \\
\text { satisfaction } \\
\text { of EU } \\
\text { policies } \\
\end{array}$ & $\begin{array}{l}\text { Beneficiaries } \\
\text { estimates }\end{array}$ & $\begin{array}{l}\text { Beneficiaries } \\
\text { estimates }\end{array}$ \\
\hline & \multirow[t]{2}{*}{$\begin{array}{l}\text { Policies } \\
\text { effects }\end{array}$} & $\begin{array}{l}\text { Coefficient of } \\
\text { subsidies } \\
\text { distribution from } \\
\text { Pillar 1 }\end{array}$ & $\begin{array}{l}\text { Level of } \\
\text { subsidies } \\
\text { comparing to } \\
\text { the average } \\
\text { for the sector }\end{array}$ & $\begin{array}{l}\text { High } 0-0,25 \\
\text { Good } 0,26-0,45 \\
\text { Satisfactory } \\
0,46-0,6 \\
\text { Unsatisfactory } \\
0,61-0,8 \\
\text { Unsustainable } \\
0,81-1,0\end{array}$ & \multirow[t]{2}{*}{$\begin{array}{l}\text { Average for } \\
\text { the sector }\end{array}$} \\
\hline & & $\begin{array}{l}\text { Coefficient of } \\
\text { distribution of } \\
\text { investment support } \\
\text { comparing to share } \\
\text { in Net Value Added }\end{array}$ & & $\begin{array}{l}\text { High } 0-0,25 \\
\text { Good } 0,26-0,45 \\
\text { Satisfactory } \\
0,46-0,6 \\
\text { Unsatisfactory } \\
0,61-0,8 \\
\text { Unsustainable } \\
0,81-1,0\end{array}$ & \\
\hline \multirow[t]{3}{*}{$\begin{array}{l}\text { Democratic } \\
\text { management }\end{array}$} & $\begin{array}{l}\text { Representati } \\
\text { on }\end{array}$ & $\begin{array}{l}\text { Share of producers } \\
\text { represented in } \\
\text { different public } \\
\text { decision-making } \\
\text { bodies }\end{array}$ & $\begin{array}{l}\text { Producers' } \\
\text { representativ } \\
\text { eness in state } \\
\text { and local } \\
\text { authorities }\end{array}$ & Experts estimate & $\begin{array}{l}\text { Farm } \\
\text { managers } \\
\text { estimates }\end{array}$ \\
\hline & $\begin{array}{l}\text { Transparenc } \\
\text { y }\end{array}$ & Transparency level & $\begin{array}{l}\text { Level of } \\
\text { access to } \\
\text { information }\end{array}$ & Experts estimate & $\begin{array}{l}\text { Farm } \\
\text { managers } \\
\text { estimates }\end{array}$ \\
\hline & Impact & $\begin{array}{l}\text { Share of overall } \\
\text { support Net Value } \\
\text { Added of } \\
\text { agriculture }\end{array}$ & $\begin{array}{l}\text { Share of } \\
\text { subsidies in } \\
\text { income }\end{array}$ & $\begin{array}{l}\text { High } 41-100 \% \\
\text { Good } 26-40 \% \\
\text { Satisfactory } \\
11-25 \% \\
\text { Unsatisfactory } 6- \\
10 \% \\
\text { Unsustainable }\end{array}$ & $\begin{array}{l}\text { High } 41-100 \% \\
\text { Good } 26-40 \% \\
\text { Satisfactory } \\
11-25 \% \\
\text { Unsatisfactory } \\
6-10 \% \\
\text { Unsustainable }\end{array}$ \\
\hline
\end{tabular}




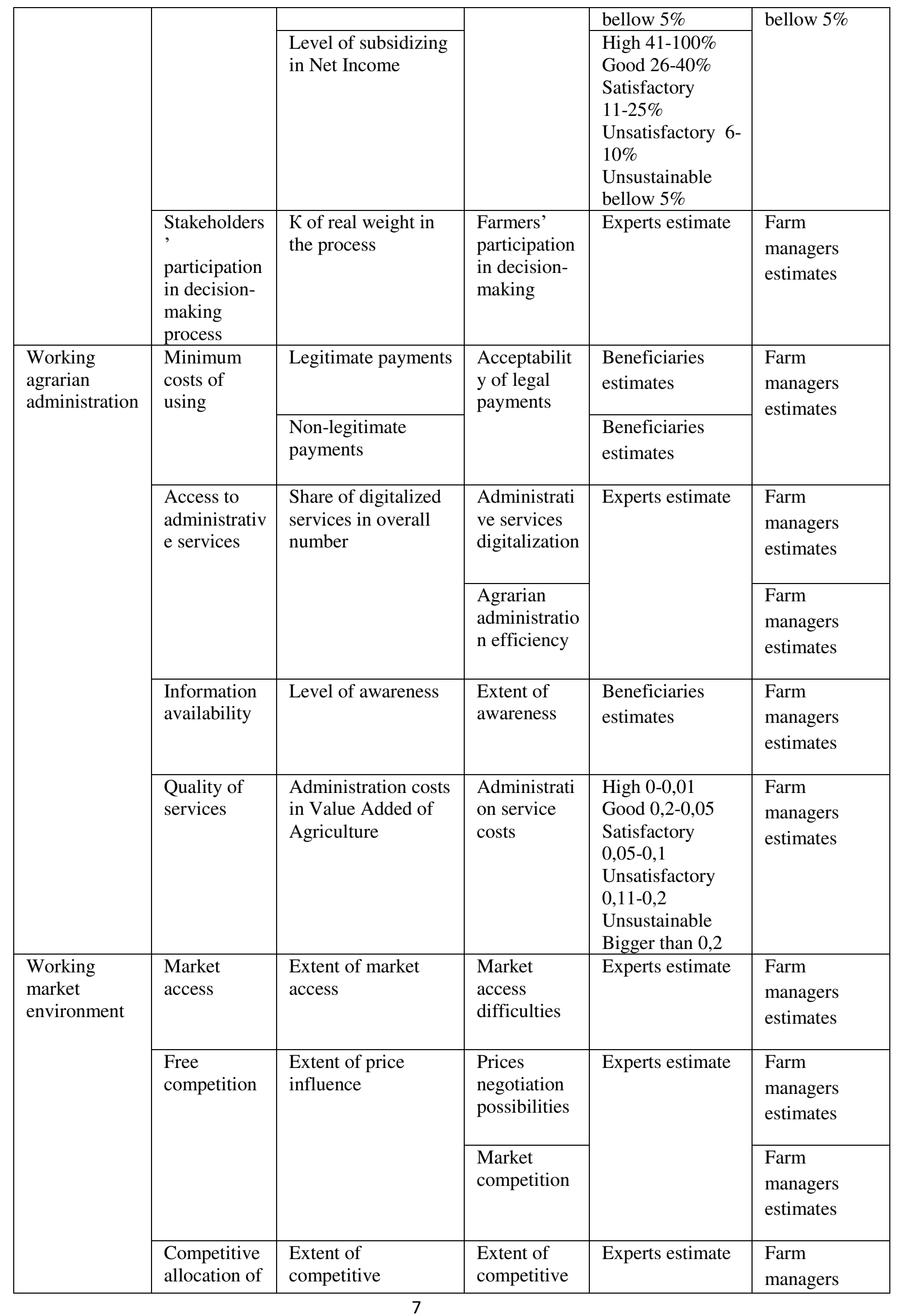




\begin{tabular}{|c|c|c|c|c|c|}
\hline & \multirow[t]{2}{*}{$\begin{array}{l}\text { public } \\
\text { resources }\end{array}$} & distribution & \multirow[t]{2}{*}{$\begin{array}{l}\text { allocation of } \\
\text { public } \\
\text { resources }\end{array}$} & & \multirow{2}{*}{$\begin{array}{l}\text { estimates } \\
\text { Farm } \\
\text { managers } \\
\text { estimates }\end{array}$} \\
\hline & & $\begin{array}{l}\text { Possibilities for } \\
\text { taking part in public } \\
\text { procurements }\end{array}$ & & Experts estimate & \\
\hline & $\begin{array}{l}\text { Resource } \\
\text { concentratio } \\
\mathrm{n}\end{array}$ & $\begin{array}{l}K \text { of concentration of } \\
\text { land resources }\end{array}$ & $\begin{array}{l}\text { K of lands } \\
\text { concentratio } \\
n\end{array}$ & $\begin{array}{l}\text { High bellow } 200 \\
\text { xa } \\
\text { Good } 200-400 \text { xa } \\
\text { Satisfactory } \\
400-600 \text { xa } \\
\text { Unsatisfactory } \\
600-800 \text { xa } \\
\text { Unsustainable } \\
\text { above } 1000 \text { xa }\end{array}$ & $\begin{array}{l}\text { High bellow } \\
200 \text { xa } \\
\text { Good 200-400 } \\
\text { xa } \\
\text { Satisfactory } \\
400-600 \text { xa } \\
\text { Unsatisfactory } \\
600-800 \text { xa } \\
\text { Unsustainable } \\
\text { above } 1000 \text { xa }\end{array}$ \\
\hline & & $\begin{array}{l}\text { Real possibilities of } \\
\text { lands extension }\end{array}$ & $\begin{array}{l}\text { Possibility } \\
\text { for lands } \\
\text { extension }\end{array}$ & Experts estimate & $\begin{array}{l}\text { Farm } \\
\text { managers } \\
\text { estimates }\end{array}$ \\
\hline \multirow[t]{4}{*}{$\begin{array}{l}\text { Good private } \\
\text { practices }\end{array}$} & $\begin{array}{l}\text { Regulation } \\
\text { implementati } \\
\text { on }\end{array}$ & $\begin{array}{l}\text { Extent of regulations } \\
\text { implementation }\end{array}$ & $\begin{array}{l}\text { Extent of } \\
\text { regulations } \\
\text { implementati } \\
\text { on }\end{array}$ & Experts estimate & $\begin{array}{l}\text { Farm } \\
\text { managers } \\
\text { estimates }\end{array}$ \\
\hline & $\begin{array}{l}\text { External } \\
\text { control }\end{array}$ & Control regulation & $\begin{array}{l}\text { Management } \\
\text { Board } \\
\text { external } \\
\text { control }\end{array}$ & Experts estimate & $\begin{array}{l}\text { Farm } \\
\text { managers } \\
\text { estimates }\end{array}$ \\
\hline & $\begin{array}{l}\text { Correctness } \\
\text { of } \\
\text { relationships }\end{array}$ & $\begin{array}{l}\text { Extent of contract } \\
\text { enforcement }\end{array}$ & $\begin{array}{l}\text { Extent of } \\
\text { contract } \\
\text { enforcement }\end{array}$ & Experts estimate & $\begin{array}{l}\text { Farm } \\
\text { managers } \\
\text { estimates }\end{array}$ \\
\hline & $\begin{array}{l}\text { Efficient } \\
\text { informal } \\
\text { system }\end{array}$ & $\begin{array}{l}\text { Level of informal } \\
\text { system efficiency }\end{array}$ & $\begin{array}{l}\text { Level of } \\
\text { informal } \\
\text { system } \\
\text { efficiency }\end{array}$ & Experts estimate & $\begin{array}{l}\text { Farm } \\
\text { managers } \\
\text { estimates }\end{array}$ \\
\hline
\end{tabular}

Source: authors

Very often individual Indicators for each Criterion and/or different Criteria, and Principles of sustainability are with unequal, and frequently with controversial levels. That significantly hardens the overall assessment requiring a transformation into "unitless" Sustainability Index and integration of estimates (Figure 2). Diverse quantitative and qualitative levels for each indicator are transformed into a Index of sustainability (ISi) applying appropriate scale for each Indicator (Bachev et al., 2018).

The Integral Sustainability Index for a particular Criterion (SI(c)), Principle (SI(p)), and Aspect of sustainability (SI(a)), and the Integral Sustainability Index (SI(o)) for evaluated agrosystem is calculated applying "equal weight" for each Indicator in a particular criterion, of each Criterion in a particular Principle, and each Principle in every Aspect of sustainability. Using "equal" rather than differentiated weight is determined by the fact that individual Sustainability Aspects, and indeed Sustainability Principles, are "by definition" equally important for the Integral Agrarian Sustainability. At the same time, differentiation of the weights of individual Criteria within each Principle and the individual Indicators within each Criteria is difficult to justify as well as to a 
great extent unnecessary (practically unimportant for the Integral assessment) having in mind the big number and small relative contribution of each Indicator ${ }^{4}$.

The Integral Index for a particular Criterion (SI(c)), Principle (SI(p)), and Aspect of sustainability (SI(a)), and the Integral Sustainability Index (SI(o)) are arithmetic averages of the Indices of composite Indicators, Criteria and Principles, calculated by the following formulas:

$$
\begin{aligned}
& \mathrm{SI}(\mathrm{c})=\sum \mathrm{SI}(\mathrm{i}) / \mathrm{n} \quad \mathrm{n}-- \text { number of Indicators in a particular Criterion; } \\
& \mathrm{SI}(\mathrm{p})=\sum \mathrm{SI}(\mathrm{c}) / \mathrm{n} \quad \mathrm{n} \text { - number of Criteria in a particular Principle; } \\
& \mathrm{SI}(\mathrm{a})=\sum \mathrm{SI}(\mathrm{p}) / \mathrm{n} \quad \mathrm{n} \text { - number of Principles in a particular Aspect, } \\
& \mathrm{SI}(\mathrm{o})=\sum \mathrm{SI}(\mathrm{a}) / 4
\end{aligned}
$$

For assessing the level of Governance and Integral sustainability of agro-systems in Bulgaria the following scale, defined by the leading experts in the area (Bachev et al. 2018) are used:

Index range 0,81-1 for a "High" level of sustainability;

Index range $0.50-0,8$ for a "Good" level of sustainability;

Index range 0,26-0,49 for a "Satisfactory" level of sustainability;

Index range 0,06-0,25 for an "Unsatisfactory" level of sustainability;

Index range 0-0,05 for "Non-sustainable" state.

Elaborated holistic framework for assessing the Governance sustainability of Bulgarian agriculture is tested using experts and stakeholders assessments, and 2018 survey data ${ }^{5}$ from the managers of 104 "typical farms" of different size and juridical type, production specialization, and ecological and geographical locations. The structure of surveyed farms approximately corresponds to the real structure of farms in different categories in Bulgaria. Classification of the surveyed farms into juridical type, size, production specialization, and ecological and geographical location is done according to the official definitions currently used in Bulgaria (and European Union).

In Bulgaria, like in many other countries, there are no official data for calculating most of the governance, socio-economic and environmental sustainability indicators at lower (farm, eco-system, subsector, regional, etc.) level (Bachev et. al., 2018). Therefore, micro and middle level assessment of socio-economic, environmental and governance sustainability is entirely based on the "original" first-hand information collected from the farm managers. The composite (Aspect and Integral) Sustainability Index of each evaluated agri-system (farming organization, agricultural subsector, agri-ecosystem, geographical region, etc.) is calculated as an arithmetic average of the Indices of relevant farms belonging to that system.

Assessment of the Governance sustainability at national (sectoral) level is evaluated in two ways - using experts and stakeholders (farmers, producers' organizations, etc.) estimates, and though aggregation of the information from the conducted farms survey.

\section{Results and Discussion}

Micro data collected from the farm managers are very important for the proper assessments of different aspects of the Governance Sustainability of agriculture generally and at various levels. Following parts of the paper presents a detailed analysis of the Governance sustainability of Bulgarian agriculture based of the original farm survey data.

${ }^{4}$ Calculations with and without differentiated weights do not find any significant variations in the sustainability levels (Bachev et.al, 2019).

${ }^{5}$ Author express their gratitude to the National Agricultural Advisory Service for conducting the survey, and to participated farm managers for providing the valuable information. 


\section{Integral Level of Governance Sustainability}

A multiple indicators assessment of the Governance sustainability level of Bulgarian agriculture indicates that the Index of Overall Sustainability is 0,51 - this represents a close to the lower ("Satisfactory") but still a "Good" level of Governance sustainability of the sector (Figure 4).

Figure 4. Levels of Governance, Economic, Social, Environmental and Integral Sustainability of Bulgarian Agriculture

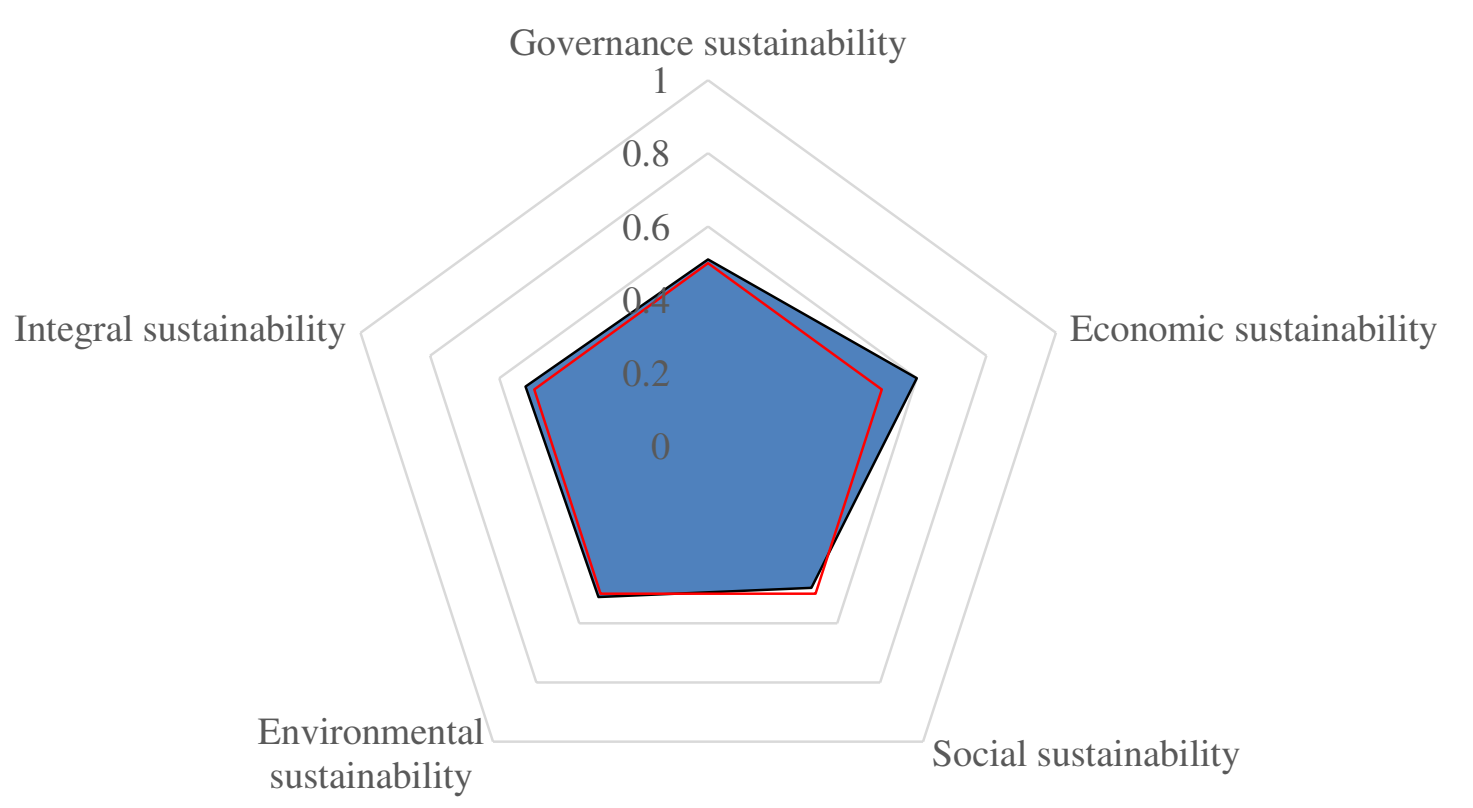

Source: survey with farm managers

Analysis of individual Indexes for the primary sustainability Principles, Criteria, and Indicators allows identifying individual components contributing to the Governance sustainability of this important sector of Bulgarian economy. For instance, the Governance sustainability of Bulgarian agriculture is relatively low because the Index for the Principle "Good Private Practices" is at "Satisfactory" level $(0,46)$ and compromises the Pillar's Integral sustainability (Figure 5). Moreover, Indices for "Good Legislative System" and "Democratic management" are quite low and at the border with the "Satisfactory" level - 0,5 and 0,51 accordingly. At the same time, Indices for the Principles "Working agrarian administration" $(0,55)$ and "Working market environment" $(0,54)$ are highest and contribute most for elevating (ensuring) the Governance Sustainability of the sector. 
Figure 5. Indices of Sustainability for Major Principles of Governance Sustainability of Bulgarian Agriculture

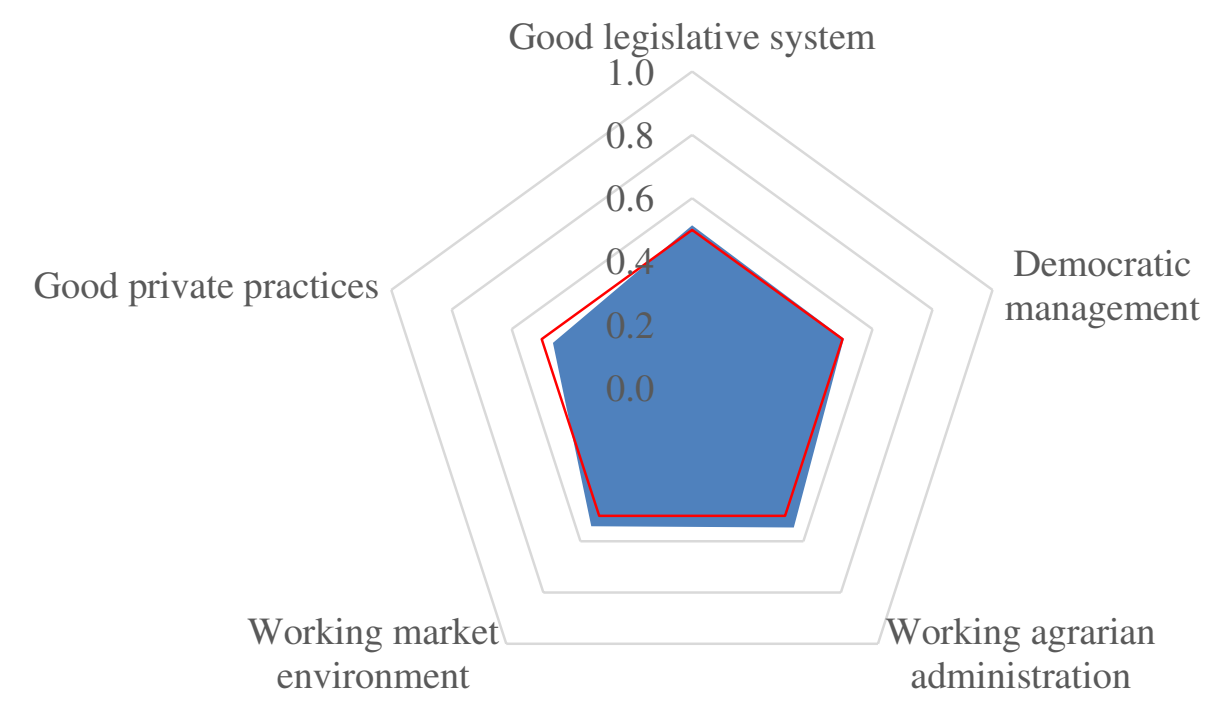

Source: author's calculation

In depth analysis of the levels of the individual Criteria and Indicators further specifies the elements that enhance or reduce country's agricultural Governance sustainability. For instance, the insufficient "Good Private Practices" is determined by the low "External control" (over management) $(0,38)$, weak "Contracts enforcement" $(0,49)$ and inferior "Informal system efficiency" (0,43) (Figure 6). Similarly, despite that the Integral Index for "Democratic management" Principle is at a "Good" level, Indices for two criteria (policies) "Impact" and "Stakeholder participation in decision-making") are quite low at satisfactory territory. Likewise, "Working agrarian administration" seems "Good" but "Access to administrative services" is actually very low $(0,34)$ at "Satisfactory" sustainability level. The same is true for the "Working market environment" which is "Good" while Index for the Criteria "Resource concentration" reviles low sustainability $(0,43)$. 
Figure 6. Indices of Sustainability for Major Criteria* of Governance Sustainability of Bulgarian Agriculture

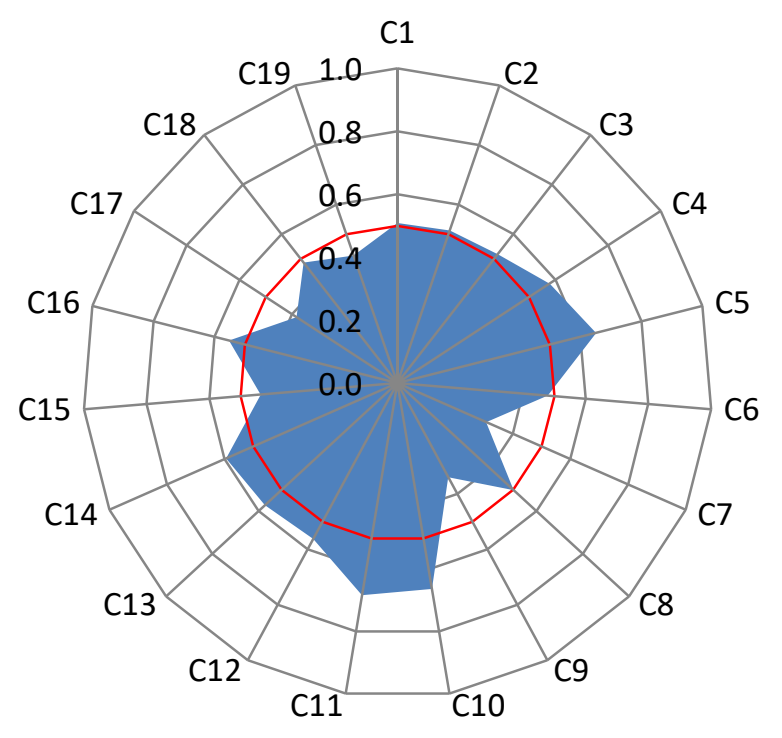

*C1-Extent of policies implementation; C2-Extent of beneficiary satisfaction of EU policies; C3-Policies effects; C4-Representation; C5-Transparency; C6-Impact; C7-Stakeholder participation in decision-making; C8-Minimum costs of using; C9-Access to administrative services; C10-Information availability; C11Quality of services; C12-Market access; C13-Free competition; C14-Competitive allocation of public resources; C15-Resource concentration; C16-Regulation implementation; C17-External control; C18Contracts enforcement; C19-Informal system efficiency

Source: author's calculation

Individual sustainability Indicators give precise information about the specific factors determining one or another values of a particular Criteria. For example, ineffective "Access to administrative services" is determined accordingly by the insufficient "Agrarian administration efficiency" $(0,31)$ and undeveloped "Administrative services digitalization" $(0,37)$ (Figure 7$)$. Likewise "Satisfactory" sustainability for the "Resource concentration" is a consequence of the (low) "Possibility for lands extension" $(0,37)$. 


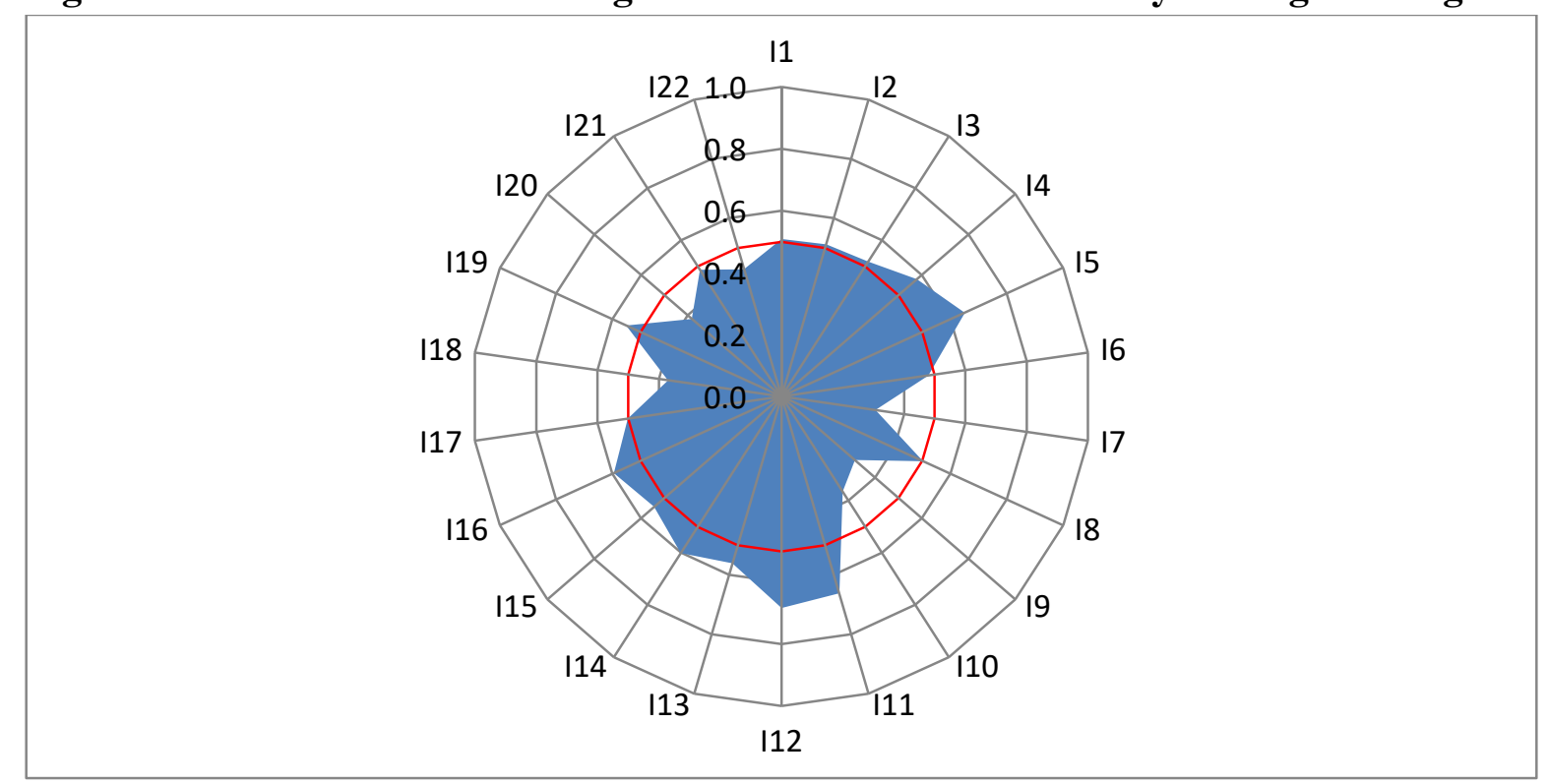

* I1-Extent of CAP implementation; I2-Extent of beneficiary satisfaction of EU policies; I3-Subsidies distribution; I4-Representativeness of state and local authorities; I5-Access to information; I6-Subsidies in Income; I7-Farmer's participation in decision-making; I8-Acceptability of legal payments; I9-Agrarian administration efficiency; I10-Administrative services digitalization; I11-Extent of awareness; I12Administration service costs; I13-Market access difficulties; I14-Market competition; I15-Prices negotiation possibilities; I16-Extent of competitive allocation of public resources; I17-Lands concentration; I18Possibility for lands extension; I19-Extent of regulations implementation; I20-Management Board external control; I21-Extent of contract enforcement; I22- Level of informal system efficiency.

Source: survey with farm managers

The low values for the Indicators help identify specific areas that require improvement through adequate changes in the institutional environment, public policy, modernization of agrarian administration, collective actions and/or management strategies. At the current stage of the development the most critical for increasing the Governance sustainability of country's agriculture are progressive improvements in following directions: "Farmer's participation in decision-making" (0,31), "Agrarian administration efficiency" $(0,31)$, “Administrative services digitalization" (0,37), "Possibility for lands extension" (0,37), "Management Board external control" (0,38), "Level of informal system efficiency" $(0,43)$, "Subsidies in Income" $(0,48)$, "Extent of contract enforcement" $(0,49)$, "Acceptability of legal payments" $(0,5)$, and "Lands concentration" $(0,5)$.

The higher levels of certain Indicators show the absolute and comparative advantages of the Bulgarian agriculture in terms of good governance and sustainable development. At the current stage of development, the most prominent of these include: "Representativeness of state and local authorities" (0,58), "Market competition" (0.6), "Extent of competitive allocation of public resources" (0.6), "Access to information" (0.65), "Extent of awareness" (0.66), and "Administration service costs" (0.68). Nevertheless, the top value(s) of the Governance sustainability Indicators in Bulgarian agriculture is relatively low. Therefore, there is a great potential for improvement of governance efficiency and further elevate the Governance and Overall sustainability. 


\section{Governance Sustainability in Major Sub-sectors}

The analysis of the Governance sustainability of different sub-sectors of Bulgarian agriculture shows that there is a great variation in the sustainability level. The highest ("Good") level of Governance sustainability is demonstrated in the "Mix livestock" production $(0,59)$, followed by the "Vegetables, flowers, mushrooms" and "Mix crop-livestock" sectors $(0,53)$ (Figure 8). Therefore, these three subsectors contribute to greatest extent for improving (maintaining) the overall Governance sustainability of Bulgarian agriculture.

On the other hand, the level of Governance sustainability in the "Grazing livestock" $(0,52)$, "Permanent crops" $(0,5)$, and "Beekeeping" $(0,5)$ is close to the average in the sector. Finally, in some major subsectors like "Field crops" $(0,47)$ and "Mix crops" $(0,49)$, the level of the Governance sustainability is "Satisfactory" and far below the general one. This means that the later subsectors decrease in a biggest degree the Integral Governance sustainability of country's agriculture.

Figure 8. Governance Sustainability in Different Sub-sectors of Agriculture, Agri-ecosystems and Agrarian Regions of Bulgaria

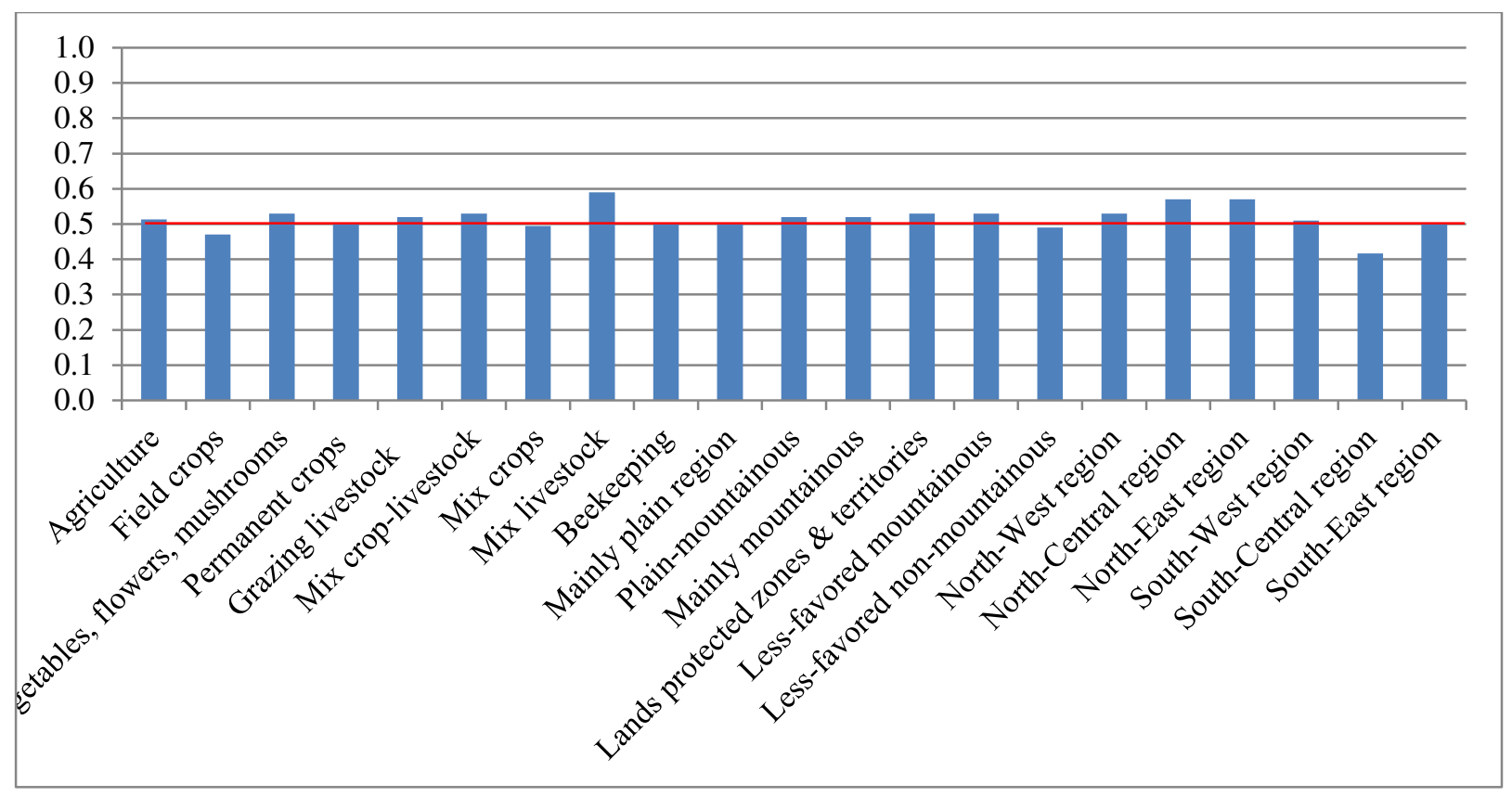

Source: survey with farm managers

The different sub-sectors of Bulgarian agriculture are characterized by significant variation of the levels of Indices of the main Principles of the Governance sustainability (Figure 9). For instance, the Principle "Good legislative system" is the best realized in the "Vegetables, flowers, mushrooms" production $(0,58)$ and "Mix-livestock" operations $(0,57)$, and the worst in "Field crops" and "Grazing livestock" sub-sectors $(0,47)$. The Principle of "Democratic management" is the best applied in the "Mix livestock" production $(0,62)$, while it is not "Satisfactory" in the "Beekeeping" $(0,46)$, and "Mix crops" and "Mix crop-livestock" sub-sectors $(0,49)$. The interior and superior levels of the Governance sustainability for particular Principles show the directions for improving the Governance sustainability in the relevant sub-sectors of agriculture.

The Principle "Working agrarian administration" is effectively applied in "Beekeeping" $(0,57)$, and "Grazing livestock" and "Mix crop-livestock" $(0,56)$, while agrarian administration 
does not "work" well in the sector of "Field crops" $(0,44)$. The sustainability for the Principle "Working market environment" is the highest in "Mix livestock" $(0,64)$, "Beekeeping" $(0,63)$ and "Mix crop-livestock" $(0,58)$. Simultaneously, market mechanisms are not working very well for the "Field crops" producers $(0,5)$. Finally, "Good private practices" are the best implemented in the subsector of "Mix livestock" $(0,62)$ and "Mix crop-livestock" $(0,5)$, while in all other subsectors they are applied only "Satisfactorily", being particularly inferior in the "Beekeeping" $(0,37)$ and "Field crops" $(0,41)$.

\section{Figure 9. Indices of the Principles of Governance Sustainability in Major Sub-sectors of Bulgarian agriculture}

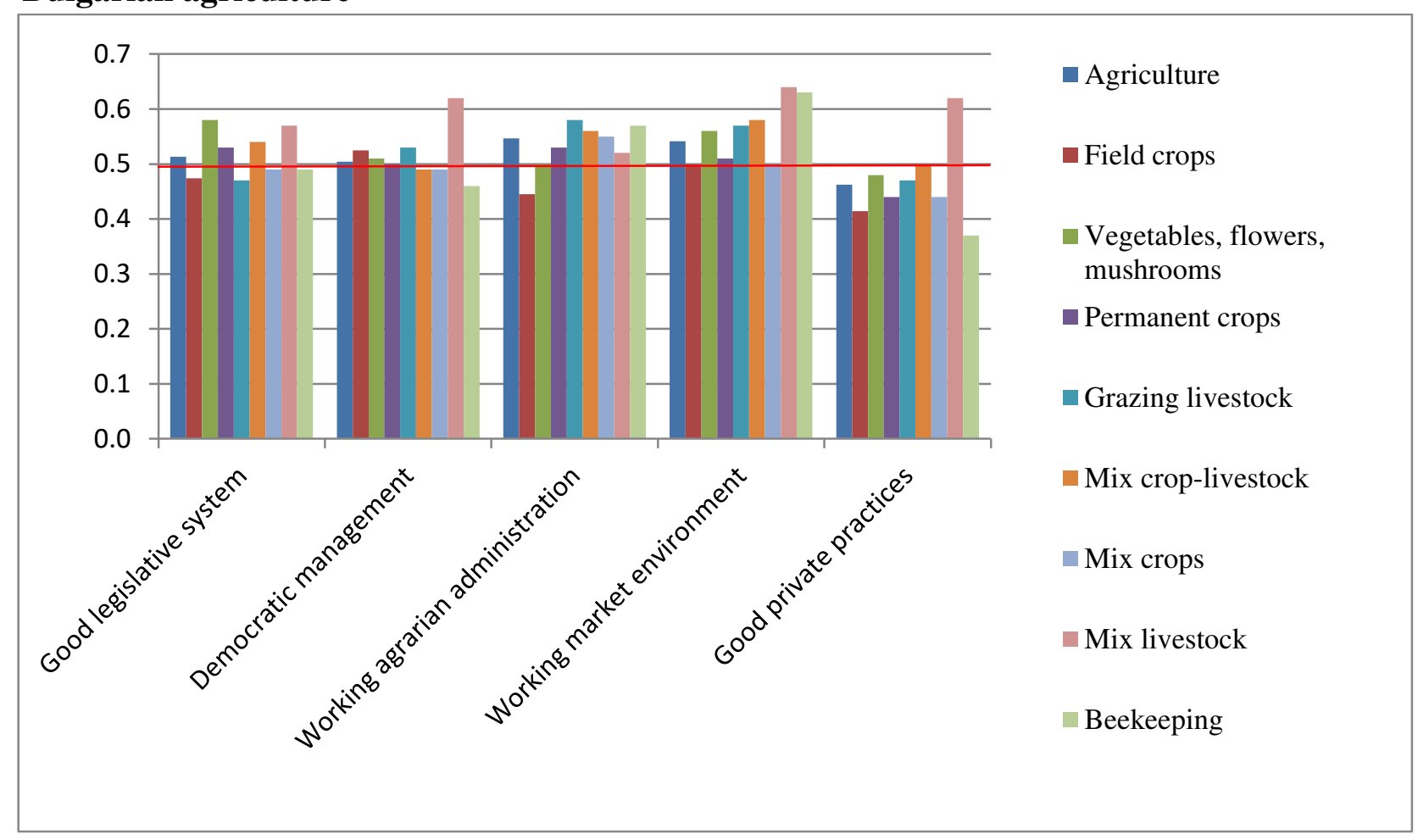

Source: survey with farm managers

In depth analysis of that type identifying inferior (critical) levels for sustainability Principles has also a high practical value since they show the specific directions (public, collective and private action areas) for improving the particular (Principle) and the Integral Governance sustainability in the evaluated subsector and agriculture in general.

Further analysis of the sustainability level for the individual Indicators allows "complete" unpacking the "critical" factors enhancing and/or decreasing the Governance sustainability of each sub-sector. Our assessment has found out that different agricultural sub-sectors in Bulgaria are characterized by a significant variation in the levels of individual Governance Sustainability Indicators.

The "Field crops" subsector of country's agriculture has a "Good" Governance sustainability for: "Market competition" $(0,68)$, "Representativeness of state and local authorities" $(0,61)$, "Market access difficulties" $(0,59)$, "Access to information" $(0,58)$, "Administration service costs $0,55)$, "Subsidies in Income" $(0,54)$, "Subsidies distribution" $(0,53)$, and marginal for the "Prices negotiation possibilities" $(0,5)$ (Figure 10$)$. At the same time for the most of the Indicators the Governance sustainability level is "Satisfactory" - "Agrarian administration efficiency" $(0,37)$, 
"Extent of regulations implementation" $(0,37)$, "Farmer's participation in decision-making $(0,37)$, "Level of informal system efficiency" $(0,38)$, "Acceptability of legal payments" $(0,41)$, "Extent of CAP implementation" $(0,42)$, "Management Board external control" $(0,43)$, "Extent of contract enforcement" (0,47), "Extent of beneficiary satisfaction of EU policies" $(0,47)$, "Extent of awareness" $(0,48)$, "Lands concentration" $(0,48)$, "Possibility for lands extension" $(0,48)$. For two indicators the value of particularly low in this type of production - "Administrative services digitalization" $(0,3)$ and "Extent of competitive allocation of public resources" $(0,33)$.

\section{Fig. 10. Governance Sustainability Indicators in Different Crop Sub-sectors of Bulgarian Agriculture}

Field crops

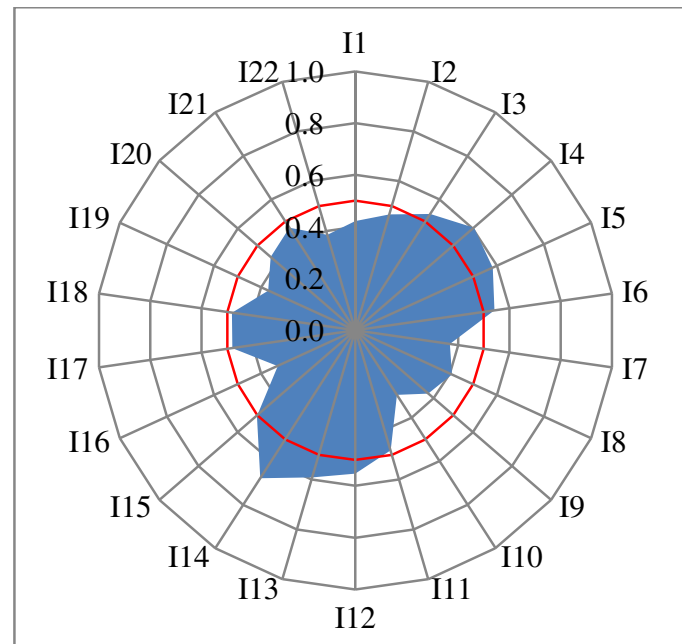

Permanent crops
Vegetables, flowers and mushrooms

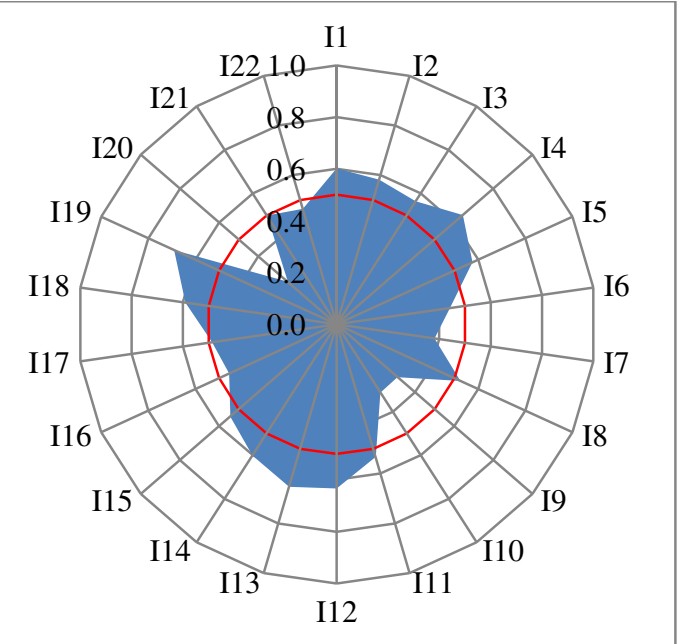

Mixed crops
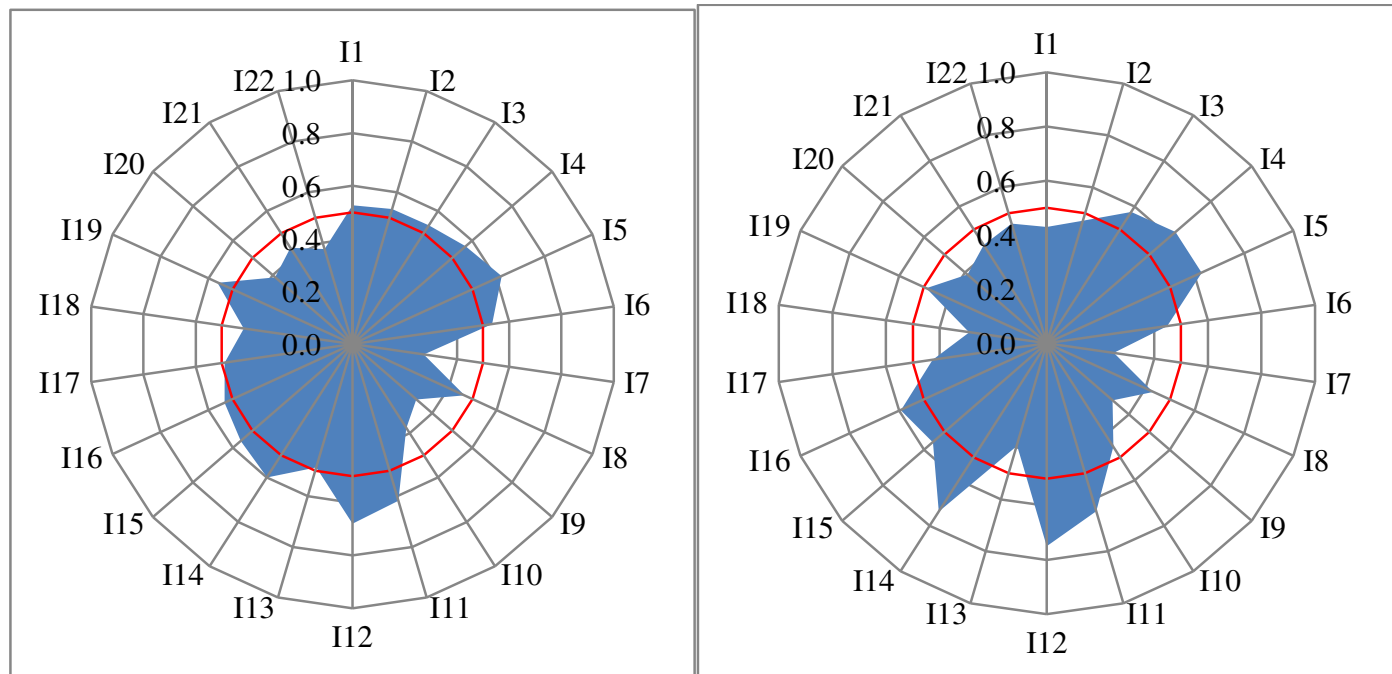

Source: survey with farm managers

The Governance sustainability of the Bulgarian "Vegetables, flowers and mushrooms" subsector is "Good" for a number of Indicators with the highest scores for: "Extent of regulations implementation" $(0,69)$, "Representativeness of state and local authorities" $(0,65)$, "Market access difficulties" $(0,65)$, “Administration service costs" $(0,63)$, "Extent of CAP implementation" $(0,6)$, and "Market competition" $(0,6)$ (Figure 10). Simultaneously, the Governance sustainability of this 
important subsectors of agriculture is at "Satisfactory" level for numerous Indicators such as: "Farmer's participation in decision-making" $(0,38)$, "Subsidies in Income" $(0,44)$, "Level of informal system efficiency" $(0,46)$, "Extent of competitive allocation of public resources" $(0,46)$, "Lands concentration" $(0,49)$, and quite low for "Agrarian administration efficiency $(0,31)$ and "Administrative services digitalization" $(0,31)$. What is more, for the Indicator "Management Board external control" $(0,25)$ the Governance sustainability is at "Unsatisfactory" level affecting adversely the overall Governance sustainability of that industry.

The Governance sustainability of the subsector of "Permanent crops" is "Good" for a number of Indicators, among which the superior are: "Administration service costs" $(0,68)$, "Access to information" (0,62), "Extent of awareness" (0,62), "Market competition" $(0,6)$ (Figure 12). At the same time, the level of Governance sustainability is "Satisfactory" for: "Administrative services digitalization" $(0,38)$, "Level of informal system efficiency" $(0,38)$, "Management Board external control" $(0,39)$, "Possibility for lands extension" $(0,42)$, "Extent of contract enforcement" $(0,43)$, "Acceptability of legal payments" $(0,47)$, "Market access difficulties" $(0,49)$ and "Lands concentration" $(0,49)$. Furthermore, the Governance sustainability of this important subsector of Bulgarian agriculture is particular low for the "Agrarian administration efficiency" $(0,32)$ and close to the border with the "Unsatisfactory" level for the "Farmer's participation in decision-making" $(0,27)$.

The Governance sustainability of the "Mix crops" productions is "Good" for several Indicators but particularly high for: "Market competition" $(0,74)$, "Administration service costs" $(0,75)$, "Extent of awareness" (0,65), "Representativeness of state and local authorities" $(0,63)$ and "Access to information" $(0,63)$ (Figure 10). Simultaneously, this subsector demonstrates "Satisfactory" Governance sustainability for: "Market access difficulties" (0,39), "Management Board external control" $(0,39)$. "Extent of CAP implementation" $(0,43)$, "Acceptability of legal payments" (0,43), "Lands concentration" $(0,43)$, "Extent of contract enforcement" $(0,43)$, "Subsidies in Income" $(0,45)$, "Administrative services digitalization" $(0,45)$, "Level of informal system efficiency" $(0,46)$, "Extent of beneficiary satisfaction of EU policies" $(0,47)$, and "Extent of regulations implementation" $(0,49)$. Besides, the Governance sustainability in this subsector is particularly low for the "Possibility for lands extension" $(0,29)$ and "Agrarian administration efficiency" $(0,32)$ and "Unsatisfactory" for "Farmer's participation in decisionmaking" $(0,25)$.

The state of the Governance sustainability in different livestock productions of the Bulgarian agriculture is similar, and a great variation in the value of the individual Indicators can be seen. The Governance sustainability in the "Grazing livestock" sub-sector is particularly "Good" for a number of areas: "Extent of awareness" $(0,72)$, "Access to information" $(0,69)$, "Market access difficulties" $(0,67)$, "Representativeness of state and local authorities" $(0,67)$, "Administration service costs" $(0,65)$, “Acceptability of legal payments" $(0,61)$ and "Extent of competitive allocation of public resources" $(0,61)$ (Figure 11). Along with this however, this production experiences "Unsatisfactory" level of governance efficiency in multiple directions - "Possibility for lands extension" (0,33), "Farmer's participation in decision-making" $(0,35)$, "Management Board external control" $(0,36)$, "Administrative services digitalization" $(0,41)$, "Subsidies in Income" $(0,42)$, "Extent of CAP implementation" $(0,43)$, "Extent of beneficiary satisfaction of EU policies" $(0,43)$, and "Level of informal system efficiency" $(0,49)$. Moreover, the level of Governance sustainability for the Indicator "Agrarian administration efficiency" $(0,27)$ is very low and close to the "Unsatisfactory" level. 


\section{Figure 11. Governance Sustainability Indicators in Different in Different Livestock Sub-sectors of Bulgarian Agriculture}

Grazing livestock

\section{Bee keeping}



Mix Crop-livestock

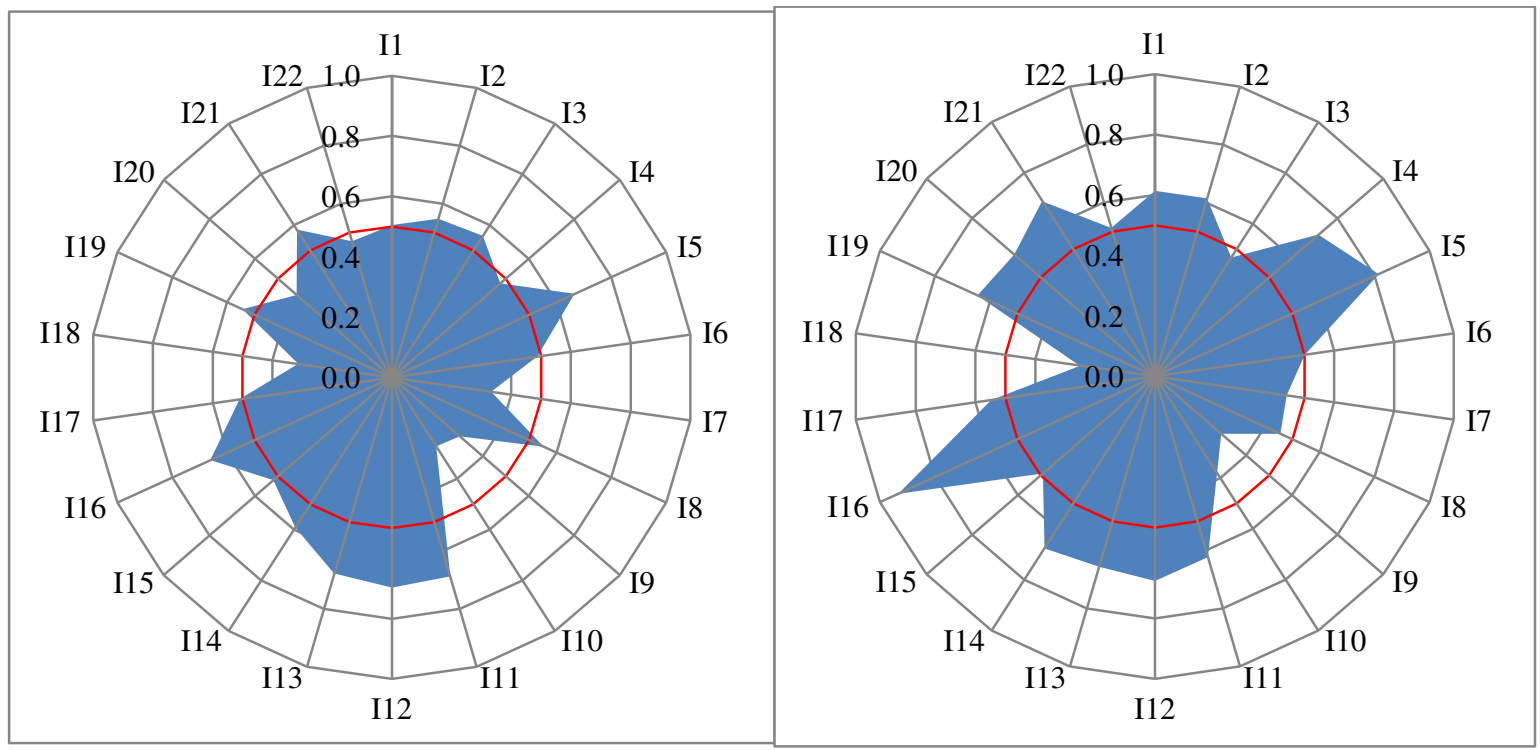

Source: survey with farm managers

The Governance sustainability in "Beekeeping" is "High" for the "Extent of awareness" $(0,84)$, and very "Good" and at the border with the top level for the "Extent of competitive allocation of public resources" $(0,8)$ (Figure 11). This sub-sector of Bulgarian agriculture also demonstrates "Good" value of sustainability Indicators for the "Market access difficulties" $(0,74)$, "Market competition" $(0,7)$ and "Administration service costs" $(0,68)$. At the same time, numerous Indicators of the Beekeeping's Governance sustainability are quite low at "Satisfactory" level such as: "Farmer's participation in decision-making" $(0,31)$, "Administrative services digitalization" $(0,31)$, "Lands concentration" $(0,37)$, "Extent of contract enforcement" $(0,39)$, "Level of informal system efficiency" $(0,39)$, "Subsidies in Income" $(0,4)$, "Extent of regulations implementation" $(0,43)$, "Subsidies distribution" $(0,46)$, and "Acceptability of legal payments" $(0,49)$. What is more, 
that subsector's Governance sustainability is "Unsatisfactory" is two areas - "Agrarian administration efficiency" $(0,25)$ and "Management Board external control" $(0,25)$.

The Governance sustainability of "Mix crop-livestock" productions of Bulgarian agriculture is "Good" for numerous Indicators among which the superior are: "Administration service costs" $(0,70)$, “Access to information" $(0,67)$, "Extent of awareness" $(0,69)$, "Market access difficulties" $(0,68)$, and "Extent of competitive allocation of public resources" $(0,66)$ (Figure 11). Simultaneously, that subsector's Governance sustainability is "Satisfactory" in multiple directions - "Agrarian administration efficiency" $(0,3)$, "Possibility for lands extension" $(0,31)$, "Farmer's participation in decision-making" $(0,33)$, "Management Board external control" $(0,42)$, "Level of informal system efficiency" $(0,47)$, "Representativeness of state and local authorities" $(0,48)$, and "Subsidies in Income" $(0,49)$. Furthermore, the state of the Governance sustainability in this subsector is quite low and close to the "Unsatisfactory" level for the "Administrative services digitalization" $(0,27)$.

The Governance sustainability of the "Mix livestock" productions of agriculture is "High" for the "Extent of competitive allocation of public resources" $(0,93)$ and "Access to information" $(0,82)$ (Figure 11). Furthermore, this industry demonstrates a very "Good" level for many indicators such as: "Representativeness of state and local authorities" $(0,72)$, "Extent of contract enforcement" (0,69), "Administration service costs" $(0,68)$, "Market competition" $(0,68)$, "Market access difficulties" $(0,66)$, "Extent of regulations implementation" $(0,65)$, "Extent of awareness" $(0,62)$, "Management Board external control" $(0,62)$, "Extent of CAP implementation" $(0,61)$, and "Extent of beneficiary satisfaction of EU policies" $(0,61)$. Nevertheless, for several key areas the Governance sustainability is at "Satisfactory" level - "Administrative services digitalization" $(0,38)$, "Farmer's participation in decision-making" $(0,44)$, "Acceptability of legal payments" $(0,46)$, "Subsidies distribution" $(0,47)$ and "Prices negotiation possibilities" $(0,49)$. What is more, for the Indicator "Agrarian administration efficiency" $(0,29)$ the Governance sustainability is quite low and near to the "Unsatisfactory" level, while for the "Possibility for lands extension" $(0,25)$ it is within "Unsatisfactory" territory.

\section{Governance Sustainability in Major Agro-ecosystems}

The Governance sustainability of major agro-ecosystems in Bulgaria also demonstrates a great variation as the highest ("Good") ones are registered for the agro-ecosystems with "Lands in protected zones and territories" $(0,53)$ and those in "Less-favored mountainous" regions (Figure 8). At the same time, the Governance sustainability of two agro-ecosystems - "Mainly plain" $(0,5)$ and "Less-favored non-mountainous" $(0,49)$ are below the national (sectoral) average, the second one being at inferior ("Satisfactory") level. Therefore, the later two type of agro-ecosystems decrease to the biggest extent the Integral Governance sustainability of Bulgarian agriculture.

The different agro-ecosystems of the country are further characterized by significant differentiations in the levels of Indices of main Principles of the Governance sustainability (Figure 12). The principle "Good legislative system" is the best implemented at "Good" level in the "Plainmountainous" agro-ecosystems $(0,56)$, while in the "Less-favored non-mountainous" $(0,45)$ and "Mainly plain" regions it is at "Satisfactory" level $(0,49)$. On the other hand, the principle of "Democratic management" is the best realized in "Less-favored non-mountainous" agro-ecosystems $(0,56)$, in the most other type it is the same or close to the sectoral average $(0,5)$, and in the "Mainly plain" regions it is at "Satisfactory" level $(0,49)$. Furthermore, the principle "Working agrarian administration" is better applied in the agro-ecosystems in "Less-favored mountainous" regions 
$(0,6)$, those with "Lands in protected zones and territories" $(0,57)$, and in "Mainly mountainous" regions $(0,55)$ while in all other types it is in below the national level. Similarly, the Principle "Working market environment" is with the highest value in the agro-ecosystems in "Mainly mountainous" regions $(0,6)$, "Less-favored mountainous" regions $(0,58)$, and "Less-favored nonmountainous" regions $(0,57)$, while in other agro-ecosystems it is worse than national one. Finally, the Governance sustainability for the Principle "Good private practices" is best implemented in the "Lands protected zones and territories" $(0,53)$, while in all other agro-ecosystems it is at "Satisfactory" level, being far worse than the sectoral average in the "Less-favored nonmountainous" regions $(0,36)$.

Figure 12. Indices of the Principles of Governance Sustainability in Major Agri-ecosystems in Bulgaria

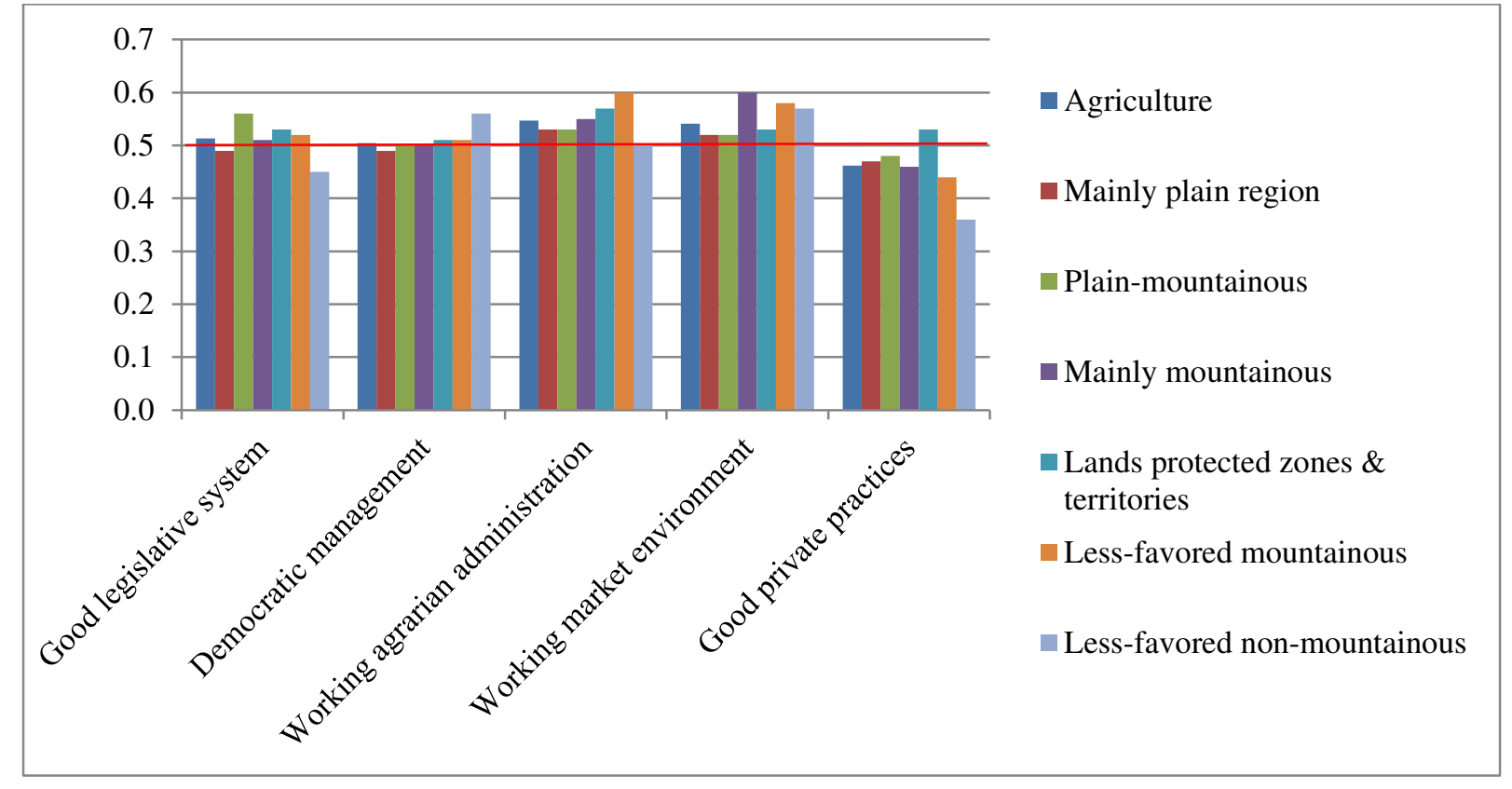

Source: survey with farm managers

Individual Indicators for the Governance sustainability of specific agro-ecosystems of the country have quite different values. Sustainability of the agro-ecosystems in "Mainly plain" regions are with the highest governance Indicators for: "Access to information" $(0,64)$, "Extent of awareness" $(0,64)$, “Administration service costs" $(0,64)$ and "Market competition" $(0,6)$ (Figure 13). At the same time, multiple factors associated with the imperfections in the governance system are "Satisfactory" decreasing the (Governance) sustainability of these agro-ecosystems: "Possibility for lands extension" (0,33), "Administrative services digitalization" $(0,34)$, "Management Board external control" $(0,4)$, "Level of informal system efficiency" $(0,43)$, "Lands concentration" $(0,45)$, "Extent of CAP implementation" $(0,49)$, "Subsidies distribution" $(0,49)$, "Subsidies in Income" $(0,49)$. Particularly low in this important areas are the Indices for the "Farmer's participation in decision-making" $(0,27)$ and "Agrarian administration efficiency" $(0,3)$.

\section{Figure 13. Governance Sustainability Indicators in Different Agri-ecosystems in Bulgaria Plain Regions Plain-Mountainous Regions}




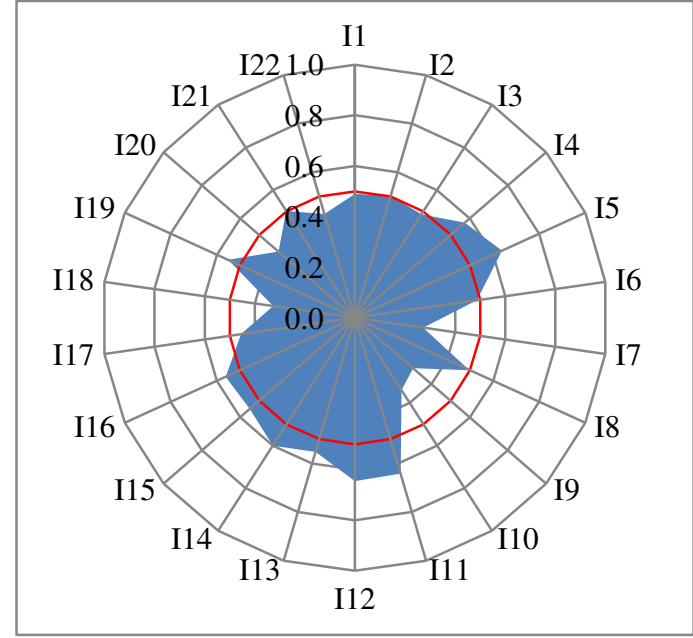

Mountainous Regions



Less-favored Mountainous

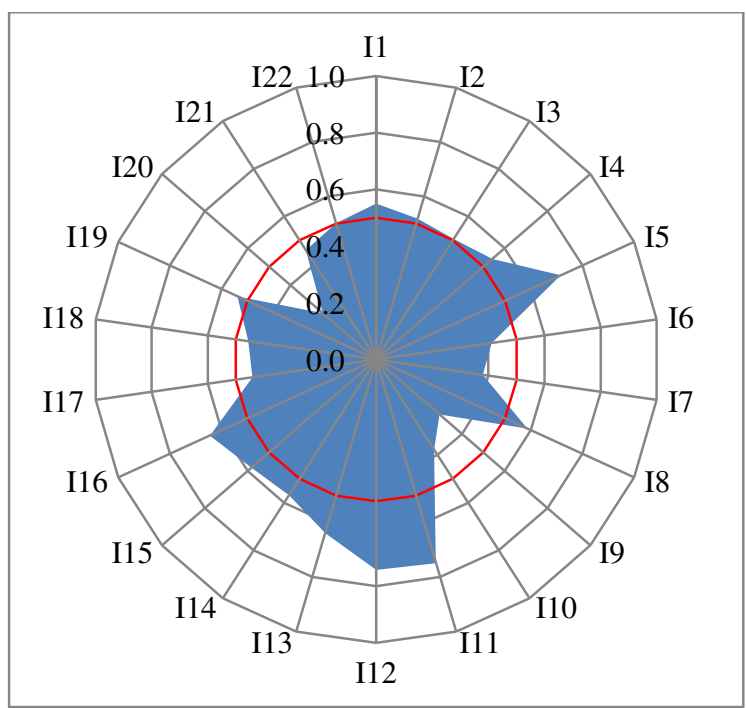

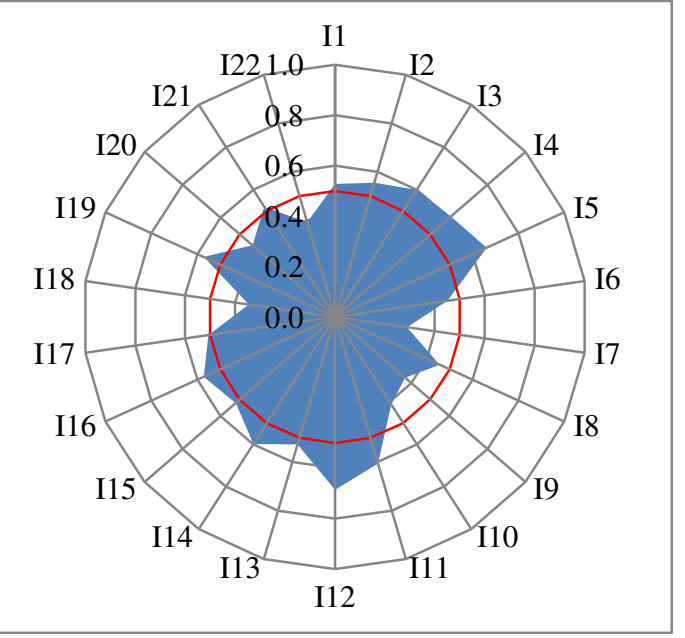

Lands Protected Zones and Territories

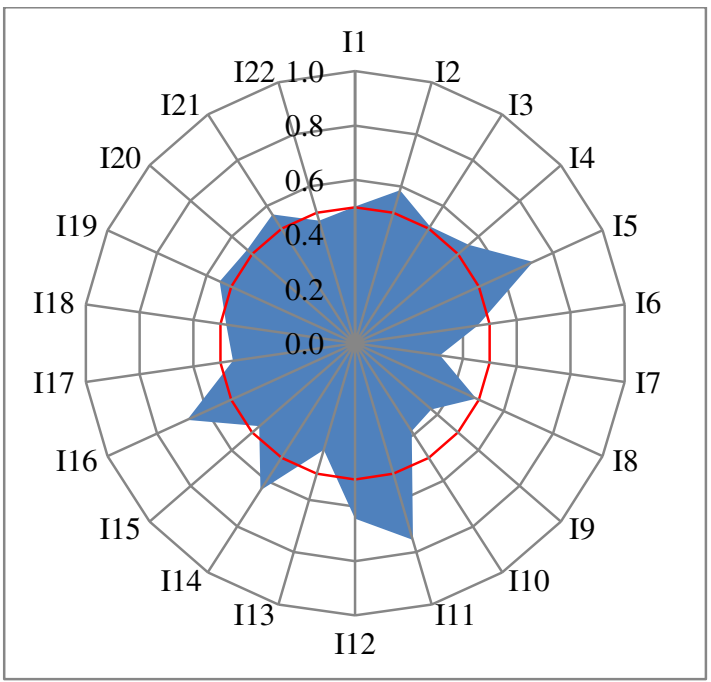

Less-favored Non-mountainous



Source: survey with farm managers

The greatest Governance sustainability Indicators for the agro-ecosystems in the "PlainMountainous Regions" of the country are: "Administration service costs" $(0,69)$, "Access to 
information" $(0,66)$, "Extent of awareness" $(0,61)$, "Representativeness of state and local authorities" $(0,61)$, "Subsidies distribution" $(0,6)$, and "Market competition" $(0,6)$ (Figure 13). Simultaneously, for a number of key Indicators level of Governance sustainability is "Satisfactory": "Possibility for lands extension" (0,35), "Agrarian administration efficiency" $(0,37)$, "Level of informal system efficiency" $(0,39)$, “Administrative services digitalization" $(0,41)$, "Management Board external control" $(0,43)$, "Subsidies in Income" $(0,45)$, and "Acceptability of legal payments" $(0,46)$, being particularly inferior for the "Farmer's participation in decision-making" $(0,29)$.

The Governance sustainability of the agro-ecosystems in "Mountainous Regions" is enhanced mostly by the "Quality of services" $(0,7)$, "Information availability" $(0,66)$, "Market access" $(0,62)$, "Resource concentration" (0,63), "Competitive allocation of public resources" $(0,61)$, and "Transparency" $(0,6)$ (Figure 13). On the other hand, the Governance sustainability of these agorecosystems is at "Satisfactory" level for the "Access to administrative services" $(0,37)$, "External control" (0,39), "Informal system efficiency" $(0,42)$, "Extent of policies implementation" $(0,48)$, "Extent of beneficiary satisfaction of EU policies" $(0,46)$, "Minimum costs of using" $(0,46)$ and "Contracts enforcement" $(0,49)$, and particularly compromised as far as the "Stakeholder participation in decision-making" is concerned $(0,29)$.

Agro-ecosystems with "Lands in Protected Zones and Territories" are with a very "Good" Governance sustainability for "Information availability" (0,75), "Transparency" $(0,72)$, "Competitive allocation of public resources" $(0,68)$, "Quality of services" $(0,65)$ (Figure 13). On the other hand, the governance sustainability of these agro-ecosystems is inferior in a number of areas: "Stakeholder participation in decision-making" $(0,32)$, "Access to administrative services" $(0,38)$, "Market access" $(0,41)$, "Impact" $(0,45)$, "Resource concentration" $(0,47)$, "Informal system efficiency" $(0,47)$, and "Minimum costs of using" $(0,49)$.

"Less-favored Mountainous" agro-ecosystems are with quite "Good" Governance sustainability for the "Information availability" $(0,75)$, "Quality of services" $(0,74)$, "Transparency" $(0,72)$, "Competitive allocation of public resources" $(0,65)$, "Market access" $(0,64)$, and "Free competition" $(0,58)$ (Figure 13). At the same time, the Governance sustainability of these agroecosystems is "Satisfactory" in terms of: "Access to administrative services" $(0,34)$, "Stakeholder participation in decision-making" $(0,38)$, "Impact" $(0,41)$, "Resource concentration " $(0,45)$, and "Contracts enforcement" $(0,46)$. Besides, these type of agro-ecosystems are with "Unsatisfactory" Governance sustainability as far as the "Management Board external control" is concerned $(0,25)$.

Finally, the agro-ecosystems in "Less-favored Non-mountainous" regions are with very "Good" sustainability for the "Market competition" $(0,78)$, "Representativeness of state and local authorities" $(0,74)$, "Lands concentration" $(0,71)$, "Extent of awareness" $(0,66)$, "Administration service costs" $(0,63)$, "Extent of competitive allocation of public resources" $(0,63)$, and "Access to information" $(0,62)$. On the other hand, for all other Indicators the Governance sustainability of this specific agro-ecosystem is "Satisfactory", and for the "Agrarian administration efficiency" even "Unsatisfactory" $(0,25)$.

\section{Governance Sustainability in Major Agro-regions}

There is a significant variation in the different aspects of Governance efficiency among administrative (and agricultural) regions of the country. The Principle of the Governance sustainability "Good legislative system" dominates in the "North-West region" $(0,6)$ and "North- 
Central region" $(0,59)$, while in the "South-Central region" $(0,38)$ and "South-West region" $(0,49)$ it is only applied "Satisfactorily" (Figure 8).

The Principle of "Democratic management" is the best realized in the "North-East region" $(0,53)$ and "South-West region" $(0,53)$, and insufficiently in the "South-Central region" $(0,4)$ and "North-West region" $(0,48)$ (Figure 14). The Principle "Working agrarian administration" is effectively applied in the "North-East region" $(0,57)$ and "North-East region" $(0,61)$. Simultaneously, that Principle is "Satisfactory" applied in the "South-Central region" $(0,49)$. Similarly, the Principle "Working market environment" are highly regarded in the "North-East region" $(0,63)$ while in the "South-Central region" $(0,45)$ and "South-East region" is inferior $(0,47)$. Finally, the "Good private practices" are the best carried out in the "North-Central region" $(0,58)$ and "North-East region" $(0,59)$ while in the three south regions of the country they are enforced "Satisfactorily" $(0,41,0,36,0,44$ accordingly).

Figure 14. Indices of the Principles of Governance Sustainability in Agro-regions in Bulgaria

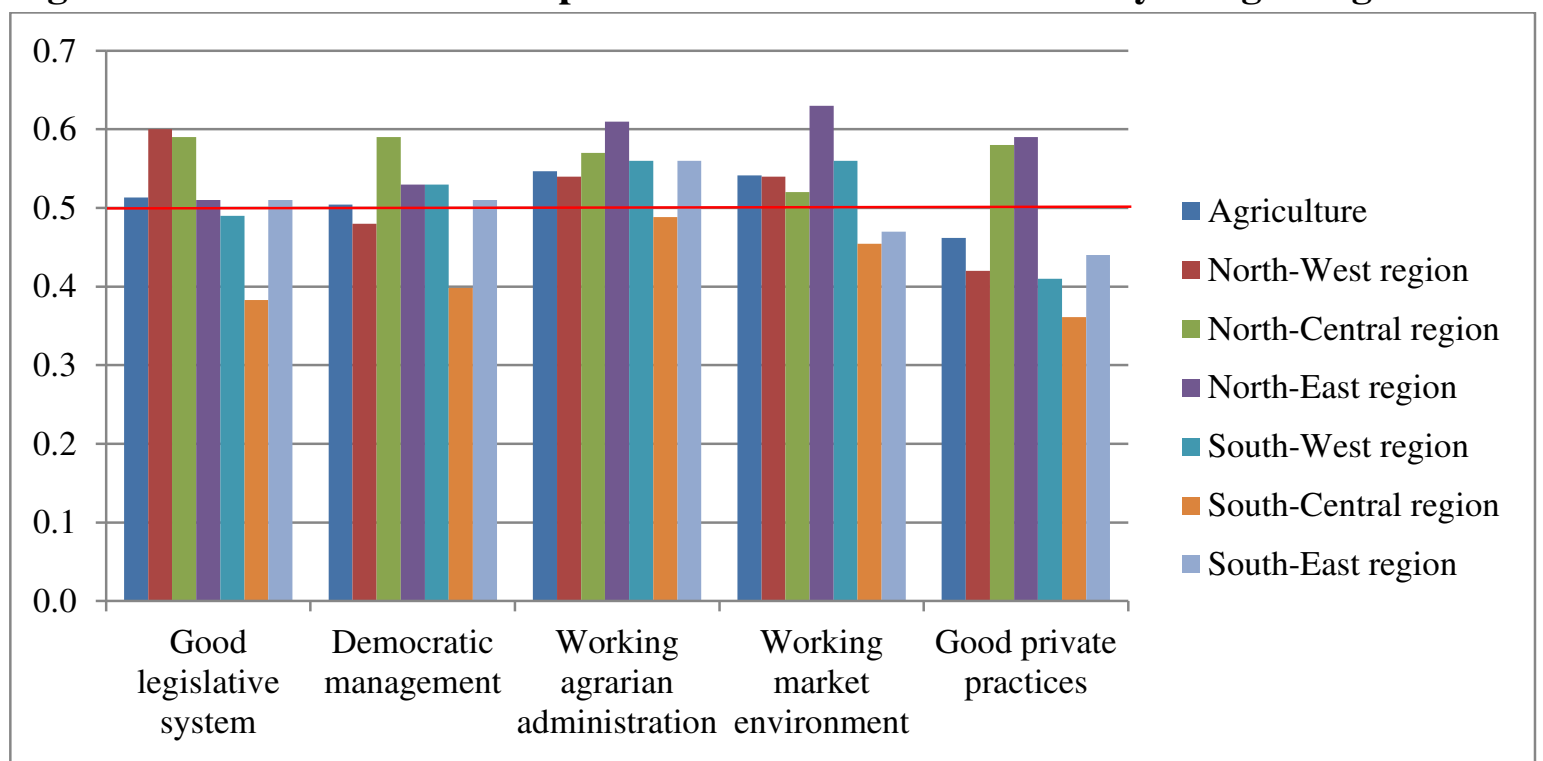

Source: survey with farm managers

There is a big variation in the levels of the Governance sustainability indicators across the territory of the country. In the "North-West Region" the highest value of sustainability is for the Indicators: "Extent of competitive allocation of public resources" $(0,74)$, "Subsidies distribution" $(0,71)$, "Extent of awareness" $(0,67)$, “Administration service costs" $(0,67)$, "Market competition" $(0,66)$, "Prices negotiation possibilities" $(0,63)$, and "Access to information" $(0,63)$. At the same time, in this agro-region the Governance sustainability is "Satisfactory" for a number of Indicators: "Agrarian administration efficiency" (0,32), "Possibility for lands extension" (0,34), "Administrative services digitalization" $(0,35)$, "Extent of contract enforcement" $(0,44)$, "Level of informal system efficiency" $(0,46)$, “Acceptability of legal payments" $(0,49)$, quite low for the "Management Board external control" (0,29), and even "Unsatisfactory" for the "Farmer's participation in decision-making" $(0,25)$ (Figure 15). 
Figure 15. Governance Sustainability Indicators in Different Agro-regions of Bulgaria North-West Region

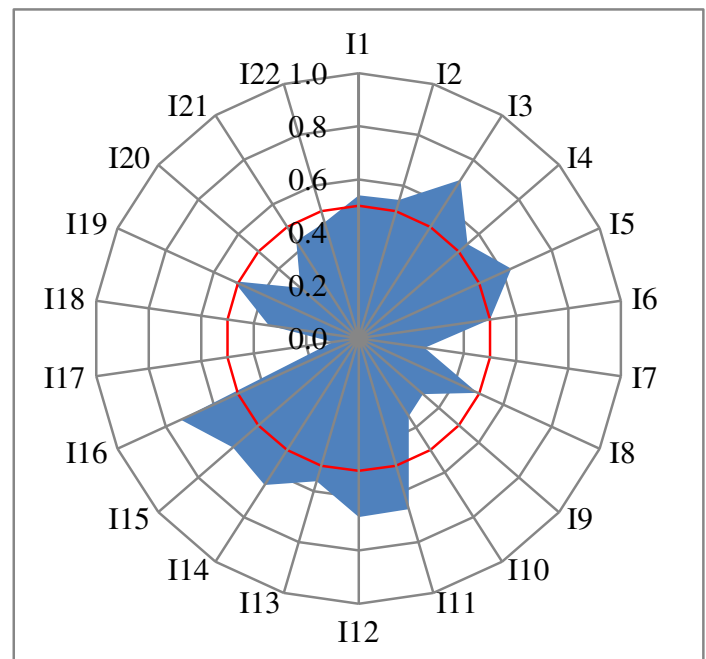

\section{North-East Region}

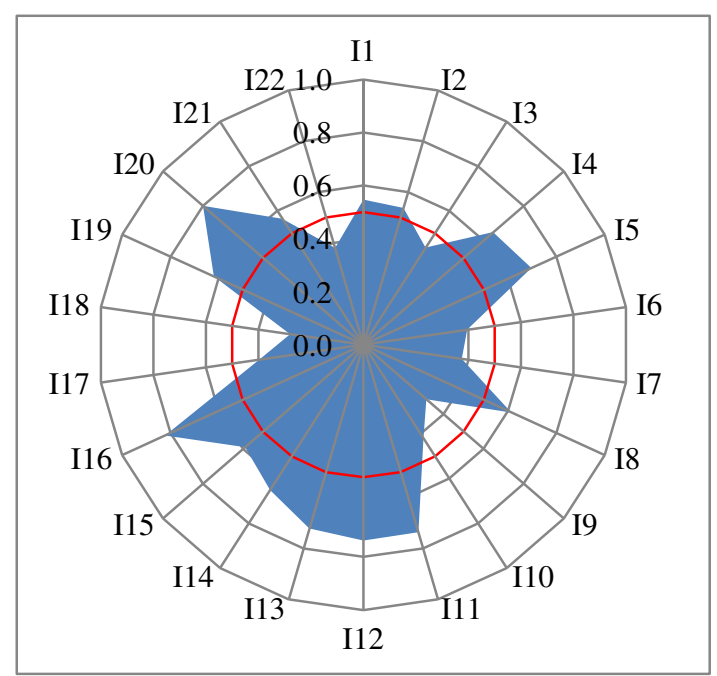

\section{South-Central Region}

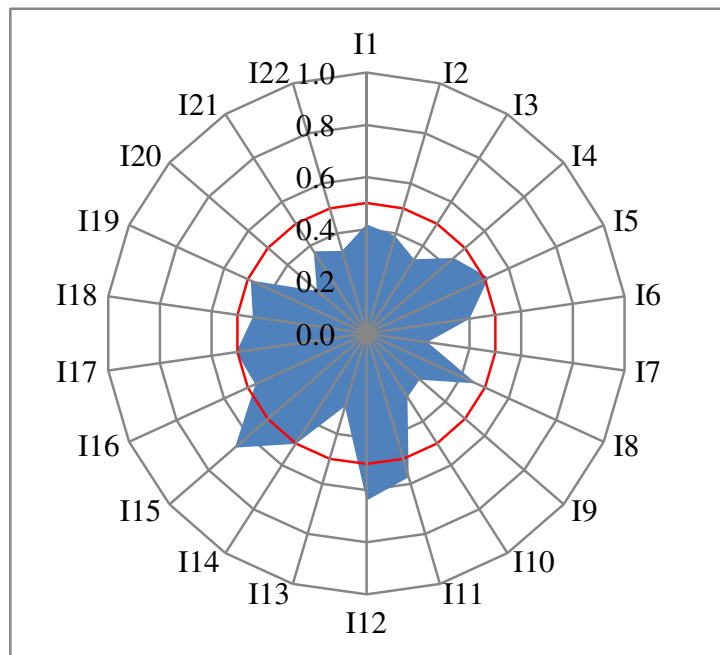

\section{North-Central Region}

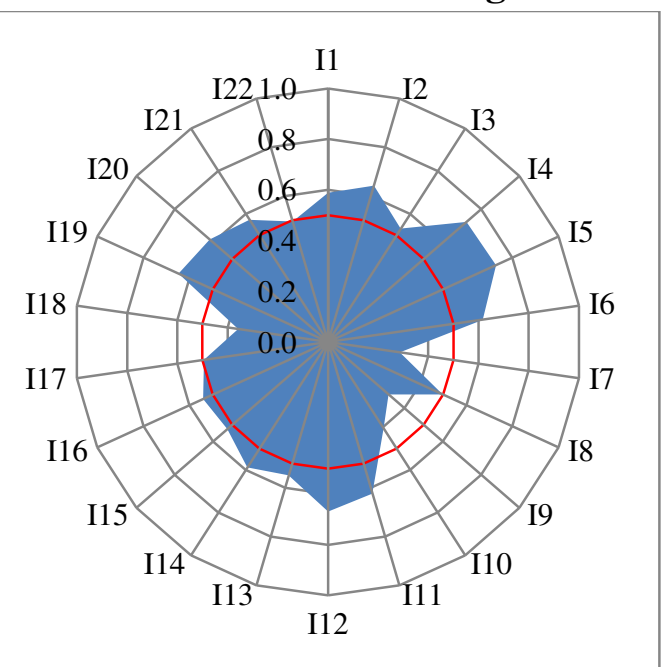

\section{South-West Region}

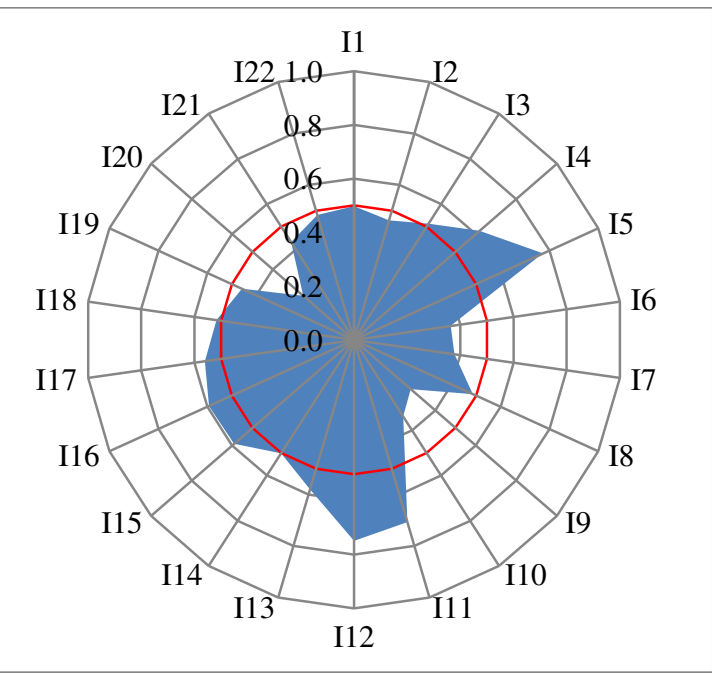

South-East Region

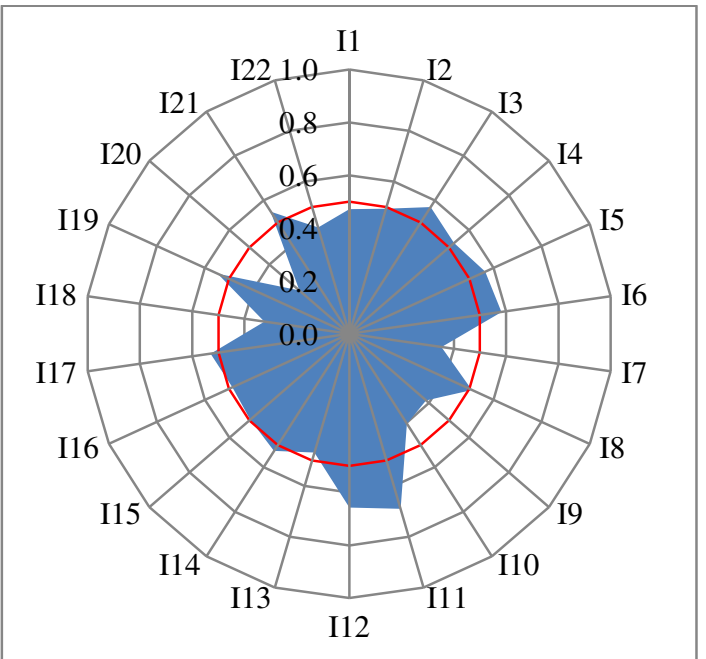

Source: survey with farm managers

The Governance sustainability of agriculture in the "North-Central Region" is very "Good" in respect to: "Access to information" $(0,73)$, "Representativeness of state and local authorities" $(0,72)$, “Administration service costs" $(0,67)$, "Extent of regulations implementation" $(0,65)$, 
"Extent of beneficiary satisfaction of EU policies" $(0,64)$, "Subsidies in Income" $(0,62)$, "Extent of awareness" (0,62), and "Management Board external control" (0.62) (Figure 15). Simultaneously, the governance system in this agro-region works only "Satisfactory" in regards to the "Farmer's participation in decision-making" (0,29), "Agrarian administration efficiency" $(0,32)$, "Possibility for lands extension" $(0,36)$, “Administrative services digitalization" $(0,41)$, and "Lands concentration" $(0,49)$.

The agrarian Governance sustainability in the "North-East Region" demonstrates a superior ("High") level for the "Extent of competitive allocation of public resources" $(0,82)$ and it is on the border with the highest level for the "Management Board external control" $(0,8)$ (Figure 15). The governance efficiency is also quite "Good" in several other directions: "Extent of awareness" $(0,74)$, “Administration service costs" $(0,74)$, "Market access difficulties" $(0,72)$, “Access to information" $(0,7)$, "Market competition" $(0,65)$, "Representativeness of state and local authorities" $(0,65)$, "Extent of regulations implementation" $(0,62)$ and "Acceptability of legal payments" $(0,61)$. Nevertheless, the Governance sustainability of agriculture in that region is at "Satisfactory" level for several key areas: "Agrarian administration efficiency" $(0,31)$, "Farmer's participation in decision-making" $(0,38)$, "Level of informal system efficiency" $(0,38)$, "Lands concentration" $(0,4)$, "Subsidies in Income" $(0,4)$, “Administrative services digitalization" $(0,42)$, and "Subsidies distribution" $(0,44)$, and especially low for the "Possibility for lands extension" $(0,28)$.

Agriculture in the "South-West Region" is with a very "Good" Governance sustainability for the Indicators such as: "Access to information" $(0,77)$, "Administration service costs" $(0,75)$, "Extent of awareness" $(0,71)$ and "Representativeness of state and local authorities" $(0,62)$. On the other hand, for many indicators the Governance sustainability of this agrarian region is at "Satisfactory" level: "Administrative services digitalization" $(0,34)$, "Subsidies in Income" $(0,36)$, "Farmer's participation in decision-making" $(0,38)$, "Extent of contract enforcement" $(0,43)$, "Extent of beneficiary satisfaction of EU policies" (0,46), "Extent of regulations implementation" $(0,46)$, "Level of informal system efficiency" $(0,48)$, and "Acceptability of legal payments" $(0,49)$. What is more, the efficiency of the governance system in that region's agriculture is close to the "Unsatisfactory" level for the "Agrarian administration efficiency" $(0,28)$, and "Unsatisfactory" for the "Management Board external control" $(0,25)$.

The "South-Central Region" agriculture is only in solid "Good" territories for two Indicators - "Administration service costs" $(0,64)$ and "Prices negotiation possibilities" $(0,67)$ (Figure 15). At the same time, the Governance sustainability of the sector is at "Satisfactory" level for numerous Indicators: "Level of informal system efficiency" $(0,33)$, "Subsidies distribution" $(0,34)$, "Extent of contract enforcement" $(0,38)$, "Extent of beneficiary satisfaction of EU policies" $(0,39)$, "Subsidies in Income" $(0,4)$, "Extent of CAP implementation" $(0,42)$, "Representativeness of state and local authorities" $(0,44)$, "Possibility for lands extension" $(0,44)$, "Acceptability of legal payments" $(0,46)$, "Extent of competitive allocation of public resources" $(0,47)$, and "Extent of regulations implementation" $(0,49)$. Furthermore, the Governance sustainability of agriculture in this region is close to the "Unsatisfactory" level for the "Agrarian administration efficiency" $(0,27)$, “Administrative services digitalization" $(0,29)$ and "Market access difficulties" $(0,29)$. On the top of that, the Governance sustainability of region's agriculture is "Unsatisfactory" in terms of "Farmer's participation in decision-making" $(0,24)$ and "Management Board external control" $(0,25)$.

Finally, the Governance sustainability of the "South-East Region" agriculture is with relatively "Good" Indicators only in respect to the "Administration service costs" $(0,66)$ and 
"Extent of awareness" $(0,69)$ (Figure 15). In many other areas the Governance sustainability of this agrarian region is at "Satisfactory" level like: "Possibility for lands extension" $(0,32)$, "Farmer's participation in decision-making" (0,35), "Agrarian administration efficiency" $(0,39)$, "Administrative services digitalization" $(0,41)$, "Level of informal system efficiency" $(0,42)$, "Extent of CAP implementation" $(0,47)$, "Market access difficulties" $(0,47)$, "Extent of beneficiary satisfaction of EU policies" $(0,49)$, and "Extent of competitive allocation of public resources" $(0,49)$. What is more, for the "Management Board external control" $(0,25)$ the Governance sustainability is at "Unsatisfactory" territory.

\section{Governance Sustainability for Major Types of Farms}

Last but not the least important, our approach let us assess what is the Governance sustainability for the various farming structures in the country, and how dominating institutional environment and modes of governance affect (contribution toward) sustainable development of major type of Bulgarian farms.

The system of governance of Bulgarian agriculture does not impact equally farms with different juridical type and size of operations. The Governance sustainability of agriculture is the highest for the "Semi-market" ("Mainly subsistence farms") and "cooperative" ("Cooperatives") sectors - the Integral Governance Sustainability Index for these type of farming organizations is much higher than the sectoral average - 0,62 and 0,56 accordingly (Figure 16). Other main juridical type of farms like "Physical Persons" and the "Middle size" farming enterprises also have higher than the average Governance Sustainability Index $(0,52)$. Therefore, all these four types of farming organizations contribute to the greatest extent to increasing (maintaining) the "Good" Governance sustainability of Bulgarian agriculture.

At the same time, for the "Small size" farms the Governance sustainability is below the national one and at the border with the "Satisfactory" level $(0,5)$. Furthermore, for the "Agro-firms" and "Big size" farming enterprises the Governance sustainability is at "Satisfactory" level - 0.47 and 0.45 accordingly. Consequently, these major type of farming enterprises diminish to the greatest extent the overall Governance sustainability of country's agriculture.

The main Principles of the Governance sustainability are applied ("work") differently in relations to various type of Bulgarian farms. The Governance Sustainability Principles "Good legislative system", "Democratic management" and "Good private practices" the most favorably affect the "Cooperatives" and "Mainly subsistence" farms (Indices of Sustainability accordingly 0,65 and 0,$7 ; 0,55$ and 0,$67 ; 0,64$ and 0,56) (Figure 17). The Governance Sustainability Principle "Working agrarian administration" is the most effectively implemented in regards to "Mainly subsistence" holdings (0,66), "Physical Persons $(0,55)$ and Middle size farms $(0,55)$. The Governance Sustainability Principle "Working market environment" is more favorable for the "Middle size" $(0,57)$ and "Small size" $(0,56)$ farms.

On the other hand, the individual Principles for the Governance sustainability of agriculture are worse applied in and adversely impact different type of farms. The Sustainability for the "Good legislative system" Principle is at "Satisfactory" level for the "Agro-firms" $(0,41)$ and "Small size" farms $(0,48)$. The sustainability Principle "Democratic management" is at "Satisfactory" level only for the "Big size" farming enterprises $(0,47)$. Implementation of the Principle "Working agrarian administration" is inferior ("Satisfactory") for the "Big size" farms $(0,4)$ and "Cooperatives" $(0,43)$; the sustainability Principle "Working market environment" does not work well for the "Big size" farms $(0,38)$ and "Agro-firms" $(0,48)$; and "Good private practices" are not applied sufficiently and 
badly affect "Agro-firms" (0,43), "Middle size" farms $(0,45)$, "Physical Persons" $(0,46)$, and "Small size" holdings $(0,47)$.

\section{Figure 16. Governance Sustainability for Major Type of Farming Organizations in Bulgaria}

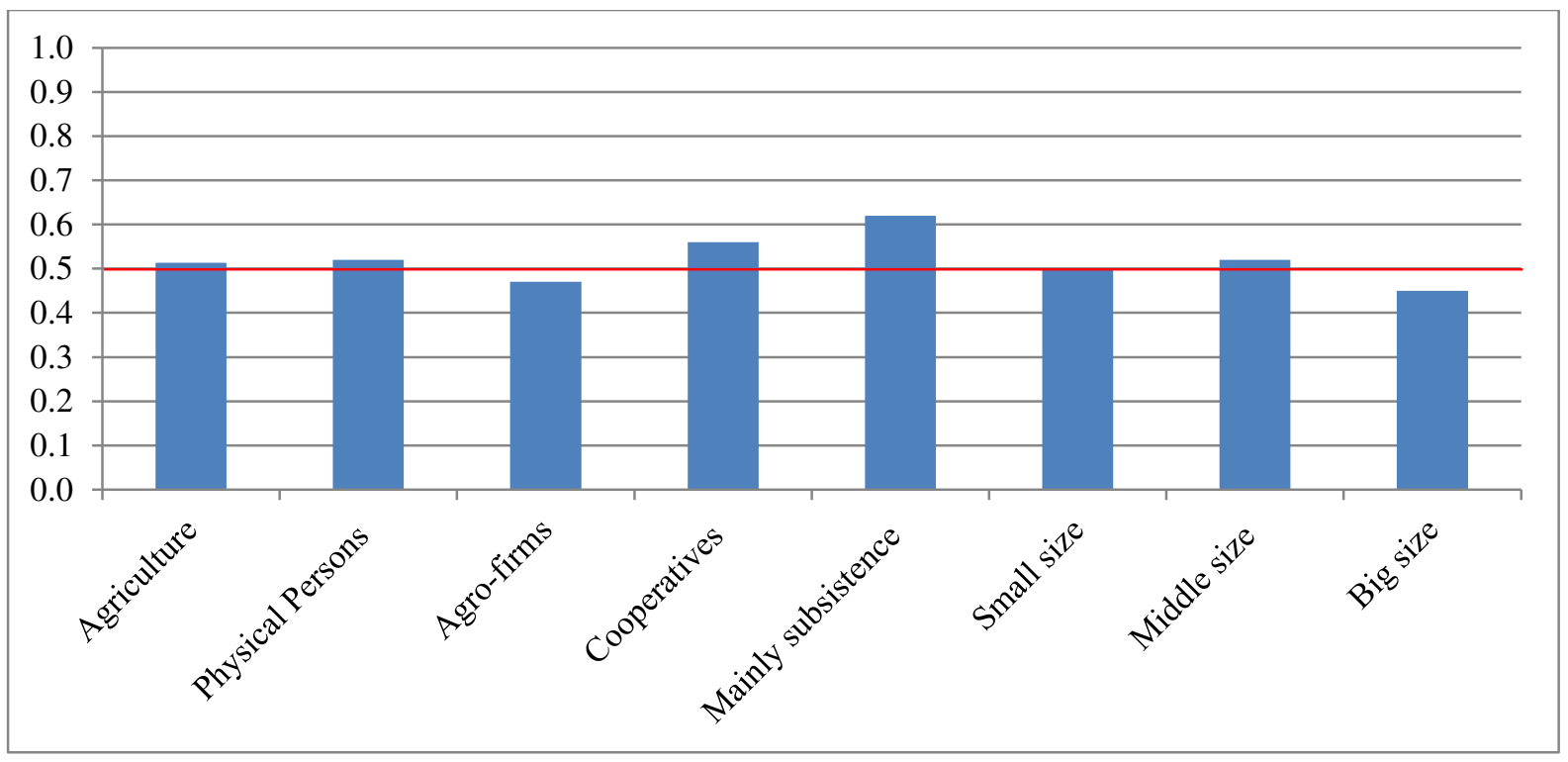

Source: survey with farm managers

Figure 17. Indices of the Principles of Governance Sustainability for Major Type of Bulgarian Farms

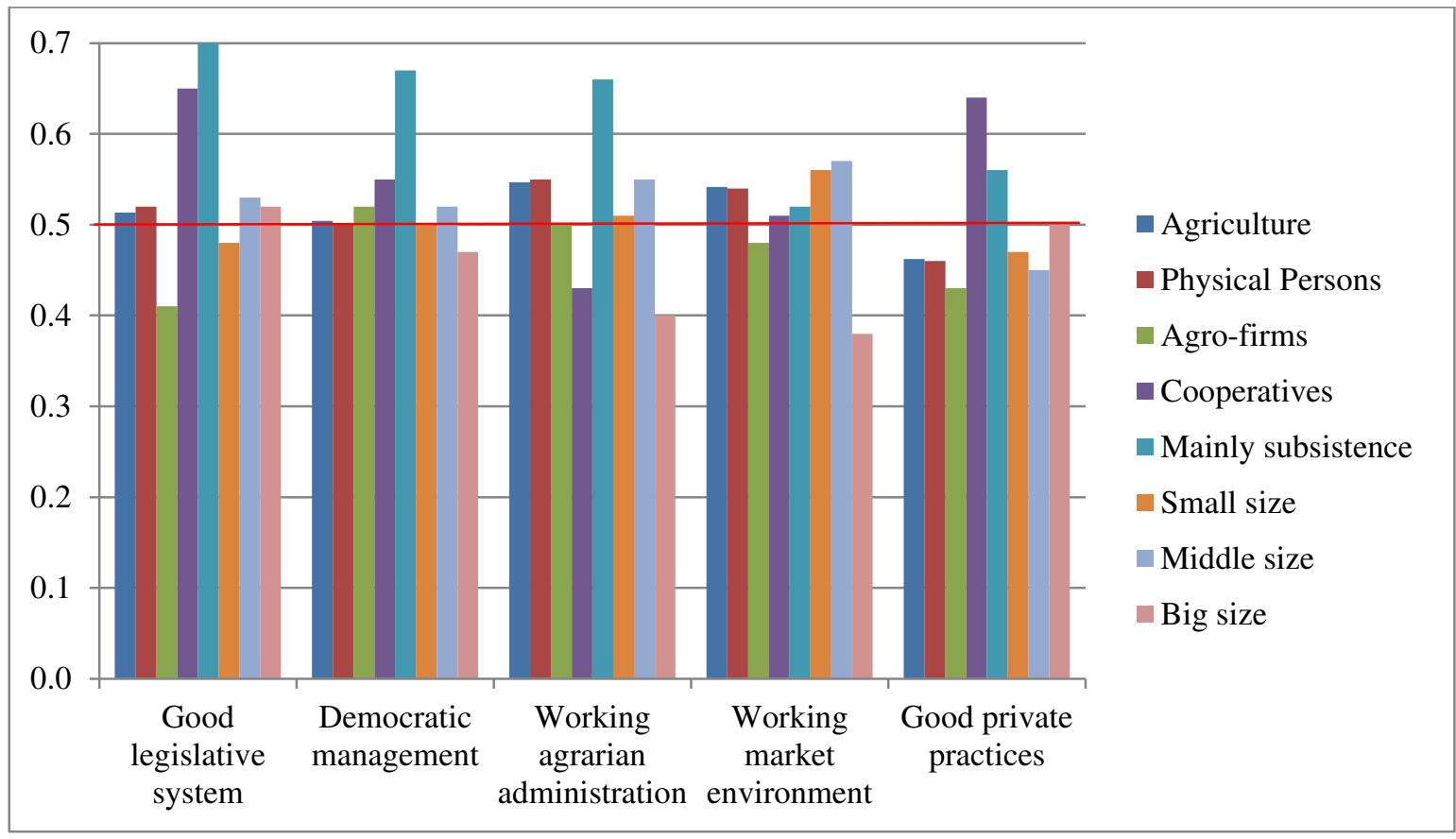

Source: survey with farm managers

The Governance sustainability of agriculture carried out in the farms of "Physical Persons" is very "Good" in terms of: "Administration service costs" $(0,69)$, "Extent of awareness" $(0,67)$, "Access to information" $(0,65)$, "Market competition" $(0,61)$, and "Extent of competitive allocation of public resources" $(0,61)$ (Figure 18). At the same time, the governance system for this 
farms work only "Satisfactory" in respect to "Farmer's participation in decision-making" $(0,31)$, "Agrarian administration efficiency" (0,31), “Administrative services digitalization" $(0,37)$, "Possibility for lands extension" (0,37), "Management Board external control" $(0,38)$, "Level of informal system efficiency" $(0,42)$, "Subsidies in Income" $(0,48)$, and "Extent of contract enforcement" $(0,48)$.

Figure 18. Impact of (Contribution to) Governance Sustainability Indicators of Major Type of Farms in Bulgaria

Physical Persons

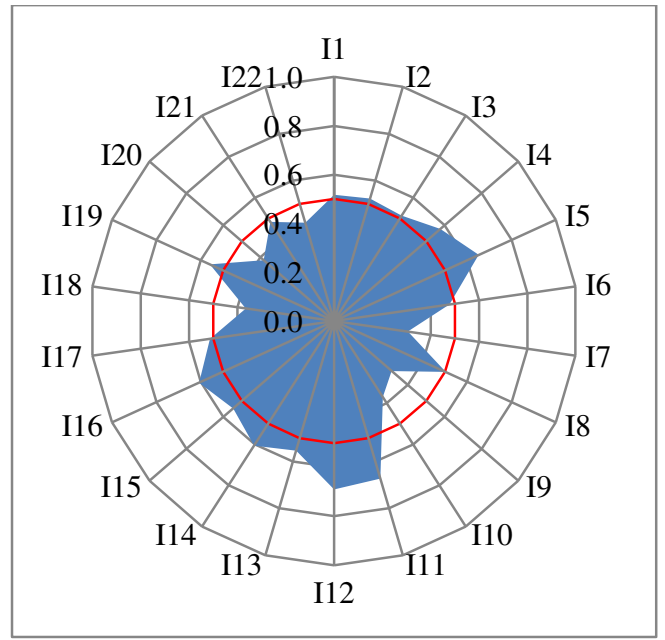

Agro-firms

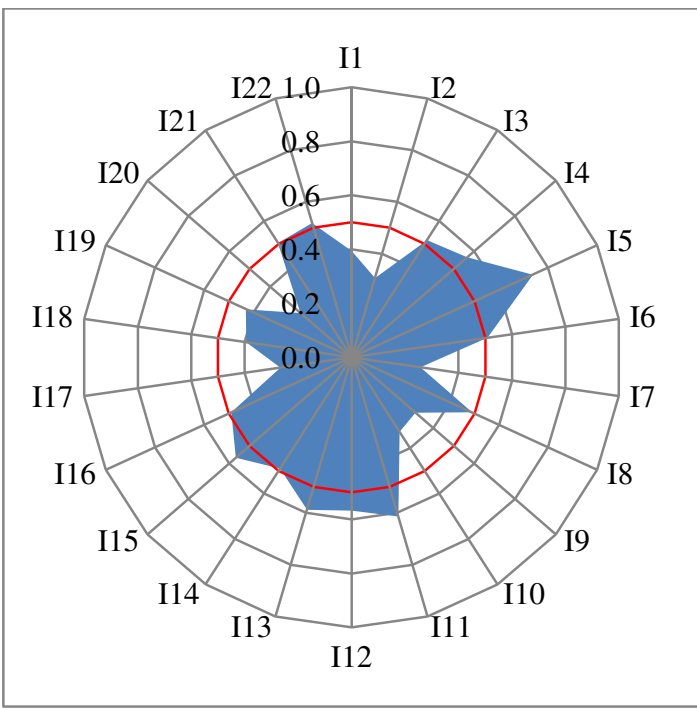

Small Size Farms

\section{Cooperatives}

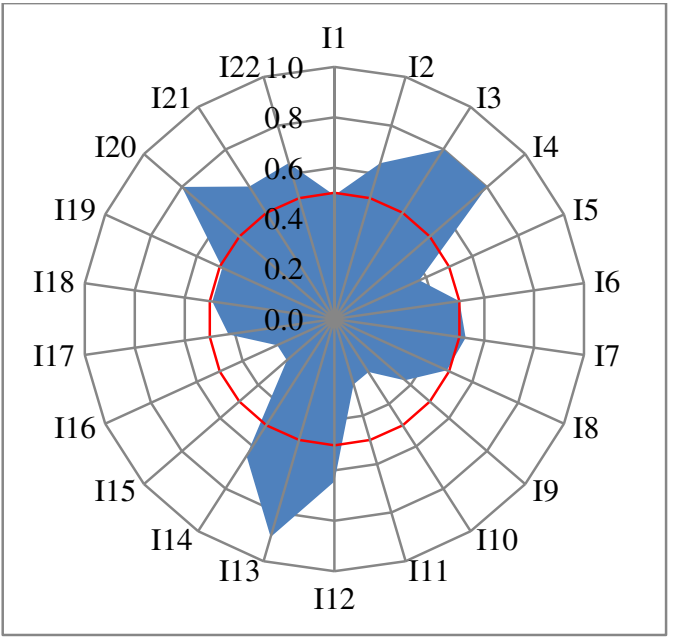

Semi-market farms

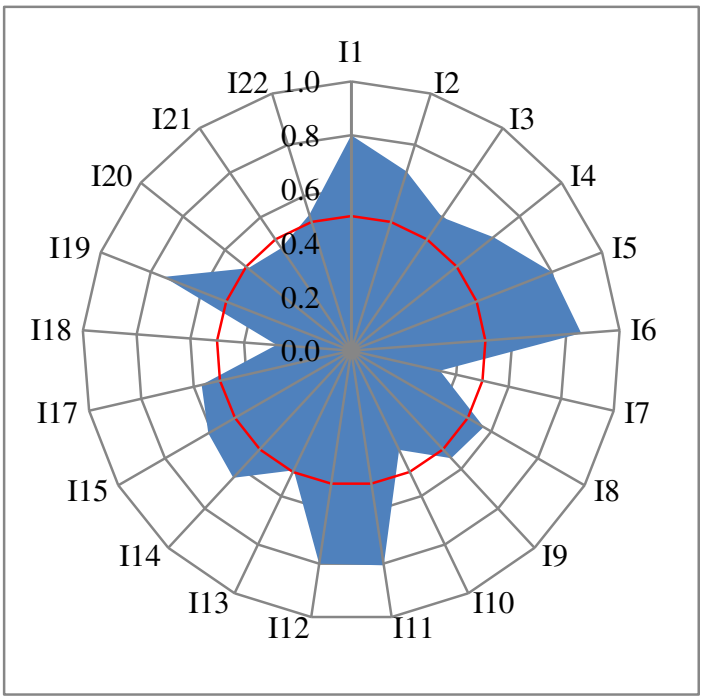

Middle Size Farms 

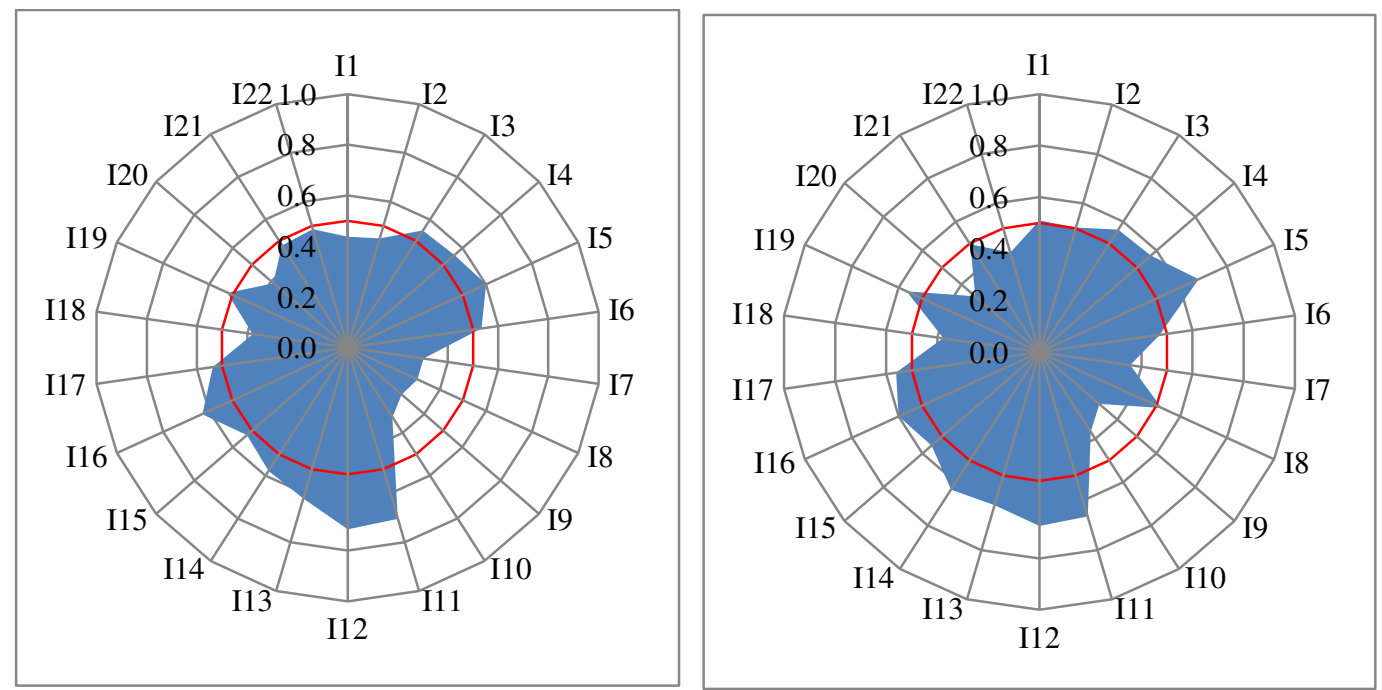

Big Size Farms

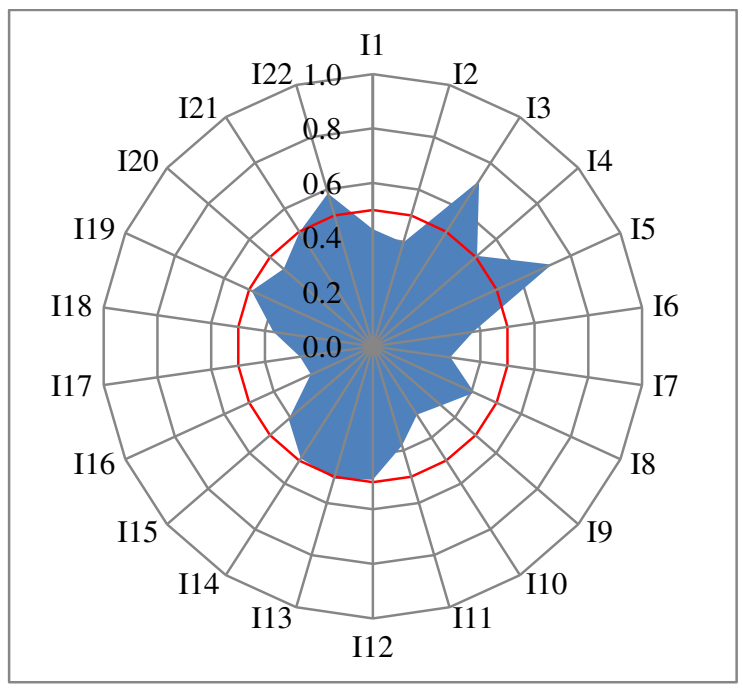

Source: survey with farm managers

The Governance sustainability of agriculture in the cooperative sector ("Cooperatives") is quite "High" for the "Market access difficulties" $(0,9)$ (Figure 18). The Cooperative farms also are in very favorable ("Good") but at the border with the "High" level) situation for three Indicators: "Subsidies distribution" (0,8), "Management Board external control" $(0,8)$, and "Representativeness of state and local authorities" $(0,8)$, as well with a very "Good" level for several other areas - "Extent of contract enforcement" $(0,63)$, "Extent of beneficiary satisfaction of EU policies" $(0,65)$, “Administration service costs" $(0,65)$, "Market competition" $(0,65)$, and "Level of informal system efficiency" $(0,65)$. Simultaneously, the Governance sustainability for the cooperatives agriculture is "Satisfactory" for the "Access to information" $(0,37)$, "Agrarian administration efficiency" $(0,37)$, "Lands concentration" $(0,43)$, "Extent of CAP implementation" $(0,49)$, “Acceptability of legal payments" $(0,49)$, "Possibility for lands extension" $(0,49), \quad$ and "Extent of regulations implementation" $(0,49)$. What is more, the Governance sustainability in the area of "Extent of awareness" $(0,27)$ is very close to the "Unsatisfactory" level while for three Indicators it is "Unsatisfactory" - "Administrative services digitalization" $(0,25)$, "Prices negotiation possibilities" $(0,25)$, and "Extent of competitive allocation of public resources" $(0,25)$. 
The Governance sustainability in "Agro-firms" is only relatively "Good" for the "Access to information" $(0,74)$ and "Extent of awareness" $(0,61)$ (Figure 18). On the other hand, for numerous Indicators the level of agrarian Governance sustainability in corporate sector is "Unsatisfactory", namely "Extent of beneficiary satisfaction of EU policies" (0,31), "Agrarian administration efficiency" (0,31), "Administrative services digitalization" $(0,33)$, "Extent of CAP implementation" (0,39), "Possibility for lands extension" $(0,39)$, "Extent of regulations implementation" $(0,43)$, “Acceptability of legal payments" $(0,49)$, "Market competition" $(0,49)$, and "Extent of competitive allocation of public resources $(0,49)$. Furthermore, the level of governance efficiency is very close to the "Unsatisfactory" level for the "Farmer's participation in decision-making" $(0,26)$ and "Lands concentration" $(0,27)$, and it is "Unsatisfactory" for the "Management Board external control" $(0,25)$.

Diverse aspects of the Governance sustainability of agriculture carried out in farming organizations of different size is also characterized with a great variation. In the "Semi-market" sector (Mainly Subsistence farms) it is "High" for the "Subsidies in Income" $(0,86)$ and "Extent of awareness" $(0,81)$, and at the border with the superior level for the "Extent of CAP implementation" $(0,8)$, “Access to information" $(0,8)$, “Administration service costs" $(0,8)$ (Figure 20). The Governance sustainability for this major type of farming organizations is also very "Good" in terms of "Extent of regulations implementation" $(0,75)$, "Extent of beneficiary satisfaction of EU policies" $(0,7)$, "Representativeness of state and local authorities" $(0,68)$, "Market competition" $(0,65)$, "Prices negotiation possibilities" $(0,61)$, and "Subsidies distribution" $(0,6)$. At the same type, the Governance sustainability in the huge "semi" market sector of Bulgarian agriculture is at "Satisfactory|" level for the "Farmer's participation in decision-making" $(0,34)$, “Administrative services digitalization" $(0,41)$, "Extent of contract enforcement" $(0,46)$, "Market access difficulties" $(0,49)$, and "Management Board external control" $(0,49)$, and quite low for the "Possibility for lands extension" $(0,28)$.

The Governance sustainability in Bulgarian small scale agriculture ("Small Size Farms") is very "Good" in regards to "Administration service costs" $(0,72)$, "Extent of awareness" $(0,7)$, "Extent of competitive allocation of public resources" $(0,63)$, "Market access difficulties" $(0,62)$, and "Access to information" $(0,6)$. On the other hand, the Governance sustainability in that dominant sector of agriculture is at "Satisfactory" level in multiple directions - "Farmer's participation in decision-making" $(0,3)$, “Acceptability of legal payments" $(0,3)$, “Administrative services digitalization" (0,33), "Possibility for lands extension" $(0,38)$, "Management Board external control" $(0,39)$, "Extent of CAP implementation" $(0,44)$, "Extent of beneficiary satisfaction of EU policies" $(0,45)$, "Extent of contract enforcement" (0.48), "Level of informal system efficiency" $(0,49)$, being particularly low for the "Agrarian administration efficiency" $(0,28)$.

The Governance sustainability of agriculture in the "Middle Size Farms" is quite "Good" for the "Access to information" $(0,68)$, "Administration service costs" $(0,67)$, "Extent of awareness" $(0,66)$, "Market competition" $(0,63)$, "Market access difficulties" $(0,62)$ and "Extent of competitive allocation of public resources" (0.6) (Figure 18). Simultaneously, the sustainability is "Satisfactory" in several key areas - "Agrarian administration efficiency" $(0,31)$, "Management Board external control“" $(0,33)$, “Farmer's participation in decision-making $(0,36)$, “Administrative services digitalization" $(0,37)$, "Possibility for lands extension" $(0,38)$, "Level of informal system efficiency" $(0,4)$ and "Subsidies in Income" $(0,47)$.

Finally, the Governance sustainability of agriculture in the large scale enterprises ("Big Size Farms") is favorably "Good" in respect to two areas - "Subsidies distribution" $(0,72)$, and "Access 
to information" $(0,72)$. However, for many indicators the Governance sustainability for this type of farming organizations are at "Satisfactory" level - "Administrative services digitalization" $(0,3)$, "Agrarian administration efficiency" $(0,33)$, "Subsidies in Income" $(0,37)$, "Possibility for lands extension" (0,37), "Extent of awareness" $(0,38)$, "Extent of beneficiary satisfaction of EU policies" $(0,4)$, “Acceptability of legal payments" $(0,41)$, "Prices negotiation possibilities" $(0,41)$, "Extent of CAP implementation" (0,43), "Management Board external control" $(0,43)$, "Possibility for lands extension" $(0,37)$, “Administration service costs" $(0,49)$, "Market competition" $(0,49)$, "Extent of regulations implementation" $(0,49)$. Moreover, the Governance efficiency for this large "subsector" of Bulgarian agriculture is close to or at "Unsatisfactory" level for the "Extent of competitive allocation of public resources" $(0,25)$, "Lands concentration" $(0,27)$, and "Farmer's participation in decision-making" $(0,29)$.

\section{Comparison of Assessments Based on Micro and Macro Data}

The comprehensive assessment of the Governance sustainability of the Bulgarian agriculture by using aggregate (sectoral) and farming (survey) data shows quite unlike results - "Satisfactory" level in the former case, and (close to the border with "satisfactory" level but still) a "Good" level in the later case (Figures 19 and Figure 4).

The Overall and Principles sustainability estimates based on the farm managers assessments are higher than those calculated on the base of the official (statistical, FADN, etc.) information, and experts and producers' organizations estimates (Figure 20). The discrepancies in the estimates for three Principles ("Democratic management", "Working market environment", and "Good legislative system") are crucial since they put the Governance sustainability in different (inferior) levels. Therefore, Governance sustainability assessments always have to be based both on (complementary) macro and micro data in order to increase accuracy and extend reliability. Besides, theoretical and practical work for the improvement of the assessment methods and data sources of the sectoral sustainability assessments (especially as far as the Governance Pillar is concerned) is to continue.

Figure 19. Levels of Governance, Economic, Social, Environmental and Integral Sustainability of Bulgarian Agriculture, calculation based on aggregate (sectoral) data

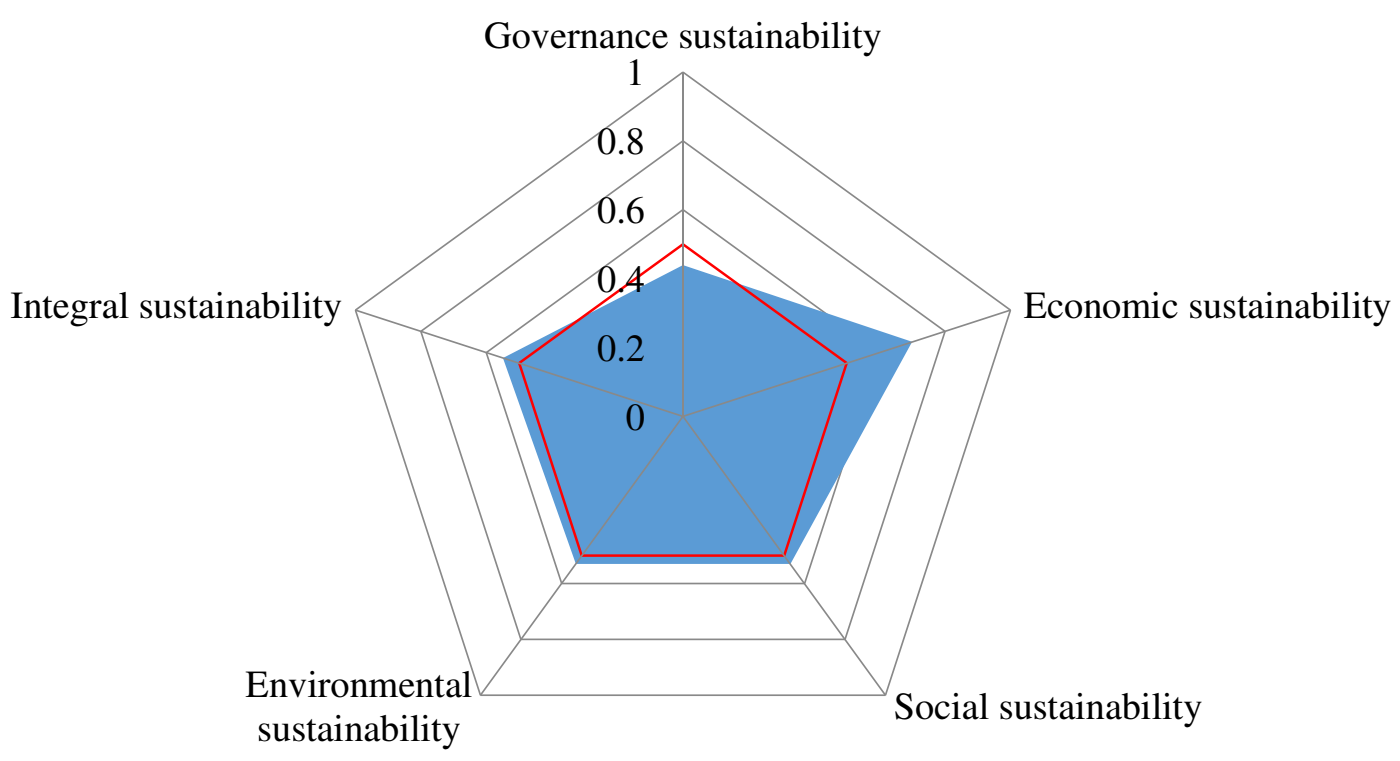


Figure 20. Sustainability Indexes for major Principles of Governance Sustainability, calculated on the base of sectoral and farm data

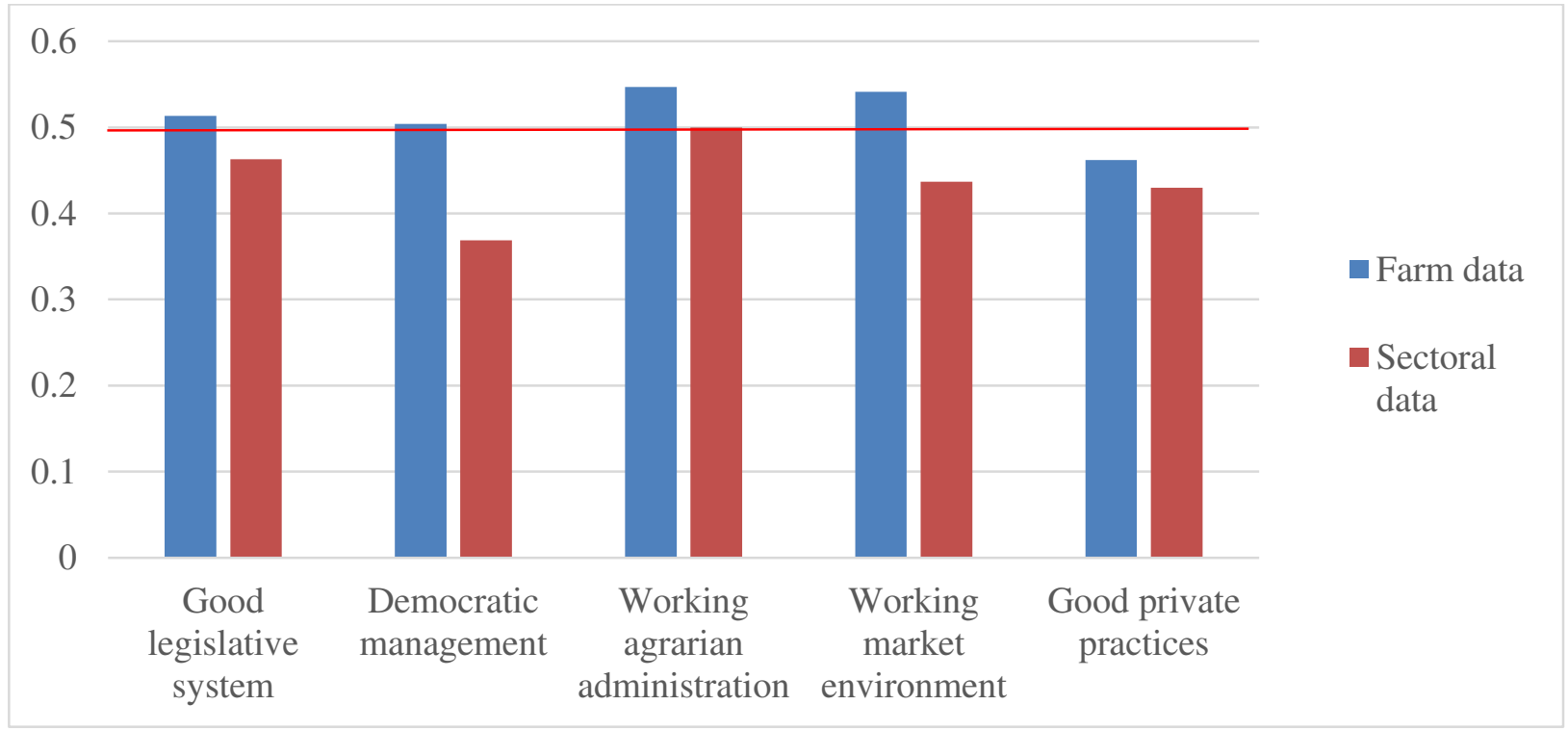

Source: authors

The inclusion of the "Governance Aspect" in the sustainability calculations changes the Integral Sustainability Index of Bulgarian agriculture using sectoral (with 0,03), and to a smaller extent farm (with 0,005) based estimates (Figure 21). However, taking into account the Governance aspect does not modify the overall ("Good") sustainability level using both type of information. The later is due to the fact that there are also differences in the Sustainability Indexes for the Economic, Social and Environmental aspects based on the aggregate (sectoral) and aggregated first hand farm data (Figure 4 and Figure 19), being particularly high for the Economic and Social sustainability (0,1 and 0,05 accordingly). The estimates based on the official aggregate sectoral data for the Economic, Social and Environmental aspects are higher than the corresponding levels based of micro farm data. Consequently, they do not affect the Integral sustainability "compensating" the contribution to the overall sustainability level of the Governance pillar. 
Figure 21. Integral Sustainability of Bulgarian Agriculture "with" and "without" Including Governance Aspect

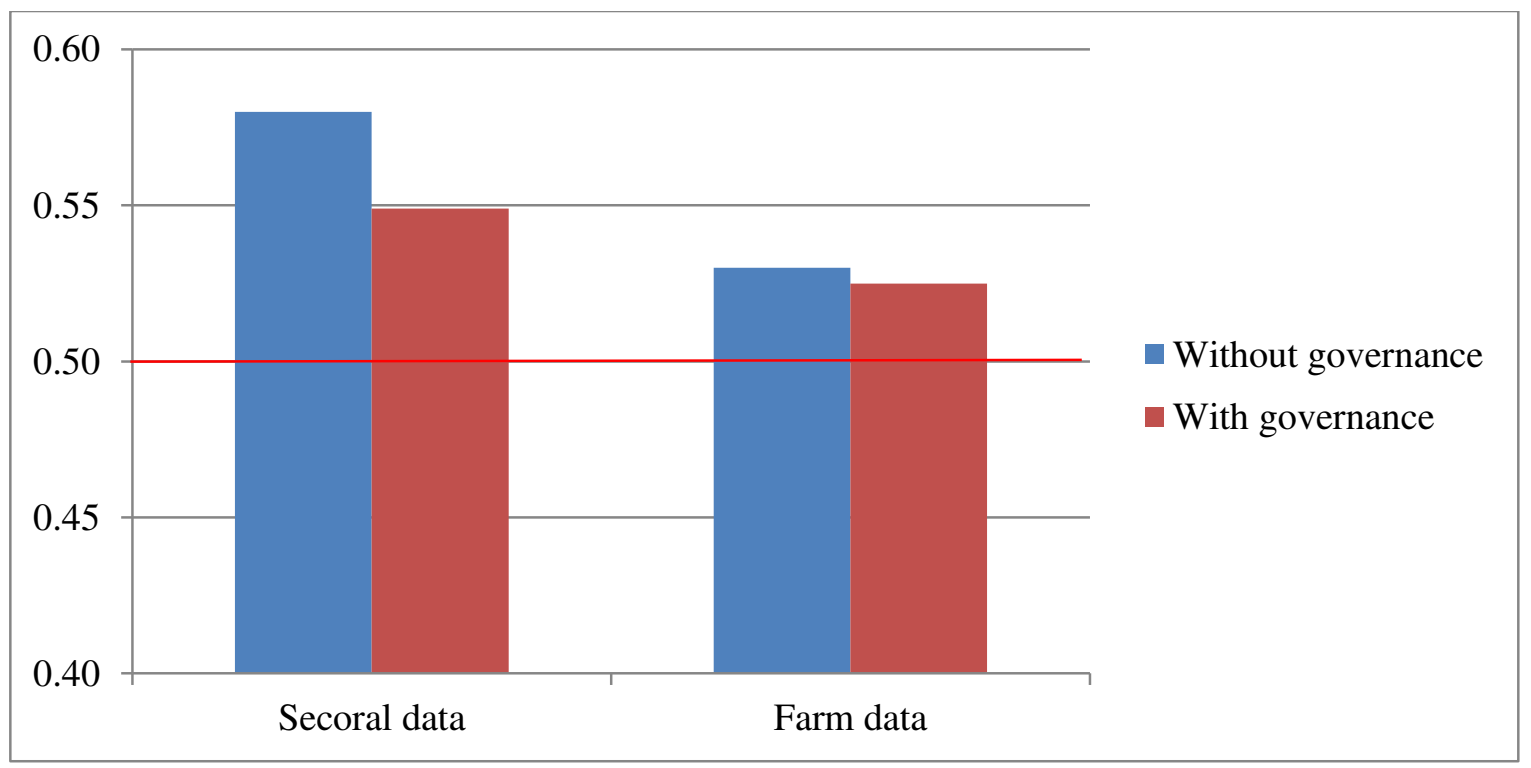

Source: Bachev et al, 2019; authors calculations

Nevertheless, the inclusion of the missing "new" and important Governance aspect is crucial since it ameliorates adequacy and precision of the sustainability assessment of Bulgarian agriculture. At the same time, all dynamics and discrepancies in the estimates between sustainability pillars and the estimates based of different (statistical, farm, etc.) type of data have to be taken into consideration in the analysis and the interpretation of results, while assessment indicators, methods and data sources further improved (Bachev et.al., 2019).

\section{Conclusions}

This study has proved that it is important to include the "missing" Governance Pillar in the assessment of the Integral sustainability of agriculture and sustainability of agro-systems of various type. Furthermore, it has demonstrated that (and how) the Governance sustainability level can be quantitatively "measured" and "integrated" in the system of overall sustainability assessment. Finally, the elaborated holistic framework has been successfully tested in Bulgarian conditions and showed promising results for proper understanding and fully "unpacking" the Governance sustainability of country's agriculture.

This first in kind comprehensive assessment of the Governance sustainability of Bulgarian agriculture let make some important specific conclusions about the state of (Governance) sustainability of diverse agro-systems, and recommendations for improvement of the managerial and assessment practices. The elaborated and experimented holistic approach gives a possibility to improve the overall and Governance sustainability assessment. Therefore, it has to be further discussed, experimented, improved and adapted to the specific conditions of evaluated agricultural systems and needs of decision-makers at different levels.

Multiple Principles, Criteria and Indicators assessment of the Governance sustainability of Bulgarian agriculture indicates that the Overall Sustainability is at a "Good" but very close to the "Satisfactory" level. Besides, there is a considerable differentiation in the level of Integral Governance sustainability of different agro-systems in the country - agricultural sub-sectors, agro- 
ecosystems, agro-regions, and type of farming organizations. What is more, the individual indicators with the highest and lowest sustainability values determine the "critical" factors enhancing and deterring the particular and integral Governance sustainability of evaluated agrosystem. Last but not least important, results on the integral agrarian sustainability assessment of this study based on micro (farm) and macro (statistical, etc.) data show some discrepancies which have to be taken into consideration in the analysis and interpretation, while assessment indicators, methods and data sources further improved.

This study reviled that much of the needed information for calculating the Governance sustainability is not readily available and have to be collected though experts' assessments, farm managers and professional associations surveys, etc. Nevertheless, a big challenge is the (level of) competency and willingness for "honest" estimated of the interviewed agents. For instance, for some highly "sensitive" questions in the conducted ("anonymous") survey many of the farm managers did not respond due to lack of opinion, experience, capability and/or reluctance for assessment, etc.

Having in mind the importance of holistic assessments of this kind for improving the agrarian sustainability in general, and the Governance sustainability of agriculture in particular, they are to be expended and their precision and representation increased. The later requires improvement of the precision through enlargement of surveyed farms and stakeholders, and incorporating more "objective" data from surveys, statistics, expertise of professionals in the area, etc.

\section{References:}

Altinay H. (2012): Global Governance Audit, Global Economy \& Development, Working Paper 49, Brookings Institution, Washington, DC.

ASA (2019): More than Green, ASA, http://www.morethangreen.es/en/ideology/foursustainabilities-cultural-economic-social-environmental-sustainability/\#sthash.IjtNJlyH.dpbs

Bachev H. (2005): Assessment of Sustainability of Bulgarian Farms, proceedings, XIth Congress of the European Association of Agricultural Economists, Copenhagen.

Bachev H. (2010): Governance of Agrarian Sustainability, New York: Nova Science Publishers.

Bachev H. (2011): Governing of Chemical and Biological Risks in Agri-food Sector: Modes, Efficiency, Challenges, in Exploring Multidiciplinary Approaches to Chemical and Biological Defence, Proceedings, DTRA \& IIBR Workshop, Israel.

Bachev H. (2013): Risk management in the agri-food sector, Contemporary Economics, Volume 7, Issue 1, 45-62.

Bachev H (2016): A Framework for Assessing Sustainability of Farming Enterprises, Journal of Applied Economic Sciences, Spring Issue, Vol XI, 1(39), 24-43.

Bachev H. (2016): Defining and Assessing the Governance of Agrarian Sustainability, Journal of Advanced Research in Law and Economics, Volume VII, Issue 4(18), 797-816.

Bashev H. (2016): Defining and assessment of sustainability of farms, Economic Studies Journal, 3, $158-188$.

Bachev,H. (2017): Socio-economic and environmental sustainability of Bulgarian farms. Agricultural and Resource Economics: International Scientific E- Journal, vol. 3 (2), 5-21.

Bachev H. (2017): Sustainability Level of Bulgarian Farms, Bulgarian Journal of Agricultural Science, 23 (1), 1-13.

Bachev H. (2017): Sustainability of Bulgarian Farming Enterprises during EU CAP Implementation, Journal of Applied Economic Sciences, 2(48), 422-451.

Bachev H. (2018): The Sustainability of Farming Enterprises in Bulgaria, Cambridge Scholars Publishing. 
Bachev H. (2018): Institutional Environment and Climate Change Impacts on Sustainability of Bulgarian Agriculture, Bulgarian Journal of Agricultural Science, 24 (4), 523-536.

Bachev H. (2020): About the Governance Pillar of Agrarian Sustainability, Журнал Еconomic Consultant, 4.

Bachev H. (2020): Measuring the New Governance Pillar of Agrarian Sustainability at Farm, Sectoral and National Level in Bulgaria, Asian Business Research Journal, Vol. 4, No. 2.

Bachev H. (2020): Governance Sustainability of Agriculture at National, Territorial and Farm Levels in Bulgaria, Social Sciences Review Quarterly, Vol. 1, No. 1, 1-13.

Bachev H. (2020): Evaluating New Governance Pillar of Sustainability of Bulgarian Agriculture, Journal of Purchasing, Logistics and Supply Chain Management System, Volume-1.

Bachev H. (2020): State and Evolution of Public and Private Research and Development in Bulgarian Agriculture, International Journal of Sustainable Development \& World Policy 9 (1), 10-25.

Bachev H. and F. Ito (2013): Impacts of Fukushima Nuclear Disaster on Japanese Agriculture and Food Chains, P. Gorawala and S.i Mandhatri (editors), Agricultural Research Updates 6, 1-76.

Bachev H., B. Ivanov, D. Toteva, E. Sokolova (2016): Agrarian Sustainability and its Governance Understanding, Evaluation, Improvement, Journal of Environmental Management and Tourism, Vol. 7, issue 4 (16), 639-663.

Bachev H., B. Ivanov, D.Toteva and E.Sokolova (2017): Agrarian sustainability in Bulgaria economic, social and ecological aspects, Bulgarian Journal of Agricultural Science, 23 (4), 519-525.

Bachev H. and D.Terziev (2017): Environmental Sustainability of Agricultural Farms in Bulgaria, Journal of Environmental Management and Tourism, Vol 8 No 5 (2017): JEMT Volume VIII Issue 5(21) Fall 2017, 968-994.

Bachev, H., Terziev, D. (2018): A Study on Institutional, Market and Natural Environment Impact on Agrarian Sustainability in Bulgaria, Journal of Environmental Management and Tourism, Vol. IX, Issue 3 (27), 452-478.

Bachev, H., Terziev, D. (2019): Sustainability of Agricultural Industries in Bulgaria, Journal of Applied Economic Sciences, Volume XIV, Issue 1(63) Spring 2019, 118-129.

Bachev H., N.Koteva, K.Kaneva, P.Yovchevska, D.Mitova, B.Ivanov, S.Alexandrova, D.Toteva, A.Sarov, E.Sokolova (2018): A System for Assessing Sustainability of Bulgarian Agriculture, IAE, Sofia.

Bachev H., N.Koteva, D.Mitova, B.Ivanov, M. Anastasova-Chopeva, D.Toteva, A.Sarov, E.Sokolova, K.Todorova, A Mitov (2019): Assessment of Sustainability of Bulgarian Aghriculture, IAE, Sofia.

Bachev H., B. Ivanov, A. Sarov (2020): Unpacking Governance Sustainability of Bulgarian Agriculture, Economic Studies, 6. 106-137.

Bachev H., B.Ivanov, A. Sarov (2020): Why and How to Assess the "Governance" Aspect of Agrarian Sustainability - The Case of Bulgaria, Agricultural Research Updates. Volume 30. Editors Prathamesh Gorawala and Srushti Mandhatri, New York, Nova Science Publisher.

Bachev H., B. Ivanov, A. Sarov (2021): Assessing Governance Aspect of Agrarian Sustainability in Bulgaria, Bulgarian Journal of Agricultural Sciences, 3.

Baeker G. (2014): Fourth Pillar of Sustainability, Economicdevelopment.org, February 18, 2014, http://economicdevelopment.org/2014/02/fourth-pillar-of-sustainability-2/

Bhuta N. and G.Umbach (2014): Global Governance by Indicators, European University Institute, http://globalgovernanceprogramme.eui.eu/global-governance-by-indicators/

Bell S. and Morse S. (2008): Sustainability Indicators: Measuring the Immeasurable? Earthscan: London.

Brklacich M., Bryant C. and B.Smith (1991): Review and appraisal of concept of sustainable food production systems, Environmental Management, 15(1): 1-14.

Bosselmann K., R. Engel, and P. Taylor (2008): Governance for Sustainability - Issues, Challenges, Successes, IUCN, Gland, Switzerland. 
Burford G., E. Hoover, I. Velasco, S. Janoušková, A. Jimenez, G. Piggot, D. Podger and M. Harder (2013): Bringing the "Missing Pillar" into Sustainable Development Goals: Towards Intersubjective Values-Based Indicators, Sustainability 2013, 5, 3035-3059; doi:10.3390/su5073035

City of Brooks (2019): Municipal Sustainability Plan, Five Pillars, City of Brooks https://www.brooks.ca/211/Sustainability

Cruz F., Y. Mena, V. Rodríguez-Estévez (2018): Methodologies for Assessing Sustainability in Farming Systems, in S. Gokten and P. Okan Gokten Sustainability Assessment and Reporting,, IntechOpen, DOI: 10.5772/intechopen.79220.

CoastalWiki (2019): Measuring sustainability: The self-assessment of sustainability using indicators and a means of scoring them, Coastal Wiki, http://www.coastalwiki.org/wiki/Measuring_sustainability

EC (2001): A Framework for Indicators for the Economic and Social Dimensions of Sustainable Agriculture and Rural Development, European Commission.

Edwards C.,R.Lal, P.Madden, R.Miller and G.House (editors) (1990): Sustainable Agricultural Systems, Soil and Water Conservation Society, Iowa.

EU (2019): European Governance, EU, https://eur-lex.europa.eu/summary/glossary/governance.html FAO (2013): SAFA. Sustainability Assessment of Food and Agriculture systems indicators, FAO.

Fraser E., Dougill A., Mabee W., Reed M., McAlpine P. (2006): Bottom up and top down: Analysis of participatory processes for sustainability indicator identification as a pathway to community empowerment and sustainable environmental management. Journal Environment Management, 78, 114-127.

IFAD (1999): Good Governance: An Overview, IFAD, Executive Board - Sixty-Seventh Session, Rome, 8-9 September 1999, EB 99/67/INF.4.

Ganev G. M. Popova, F. Bönke (2018): Bulgaria Report, Sustainable Governance Indicators 2018, SGI 2018, 2, Bertelsmann Stiftung.

Georgiev, M. (2013): Impact of the Administration Structure and Transaction Costs on the Agricultural Land Market, Trakia Journal of Sciences, 11(11), 527-534.

Gibson R. (2006): Beyond the Pillars: Sustaibaility Assessment as a Framework for Effective Integration of Social, Economic and Ecological Considerations in Significant DecisionMaking, Journal of Environmental Assessment Policy and Management, Vol. 8, No. 3, 259280.

Hansen J. (1996): Is Agricultural Sustainability a Useful Concept, Agricultural Systems 50: 117143.

Hayati D. Z. Ranjbar, and E. Karami (2010): Measuring Agricultural Sustainability, in E. Lichtfouse (ed.), Biodiversity, Biofuels, Agroforestry and Conservation Agriculture, Sustainable Agriculture Reviews 5, Springer Science, 73-100.

Kayizari C. (2018): Good Governance as a pillar of Sustainable Development in Africa, PPP https://www.aydin.edu.tr/tr-

tr/arastirma/arastirmamerkezleri/afrikam/Documents/Oturum\%203\%20-\%20GoodGovernance-as-a-pillar-for-sustainable-Development-in-Africa_CaesarKayizari.pdf

Marinov P. (2019), Index of localization of agricultural holdings and employees in the rural areas of the South Central Region for Bulgaria, Volume 25, Issue 3, Bulgarian Journal of Agricultural, pp. 464-467.

Mirovitskaya N. and W.Ascher (editors) (2001): Guide to Sustainable Development and Environmental Policy, Duke University Press, London.

Kamalia F., J.Borges, M.Meuwissen, I. Boer, A.Lansink (2017): Sustainability assessment of agricultural systems: The validity of expert opinion and robustness of a multi-criteria analysis, Agricultural Systems, Vol. 157, 118-128.

Lewandowski, I., Härdtlein M., Kaltschmitt M. (1999): Sustainable crop production: definition and methodological approach for assessing and implementing sustainability. Crop science 39:184193. 
Lopez-Ridauira S., O. Masera, and M. Astier (2002): Evaluating the sustainability of complex socioenvironmental systems. The MESMIS framework. Ecological indicators 2: 135-148.

Lowrance R., P, Hendrix, and E. Odum (2015): A hierarchical approach to sustainable agriculture, American Journal of Alternative Agriculture.

Monkelbaan J. (2017): Achieving the Sustainable Development Goals: Theoretical insights and case studies for making sustainability governance more integrative, V. R. F. Series, No. 499, INSTITUTE OF DEVELOPING ECONOMIES, JAPAN EXTERNAL TRADE ORGANIZATION.

Monkelbaan J. (2018): Governance for the Sustainable Development Goals Exploring an Integrative Framework of Theories, Tools, and Competencies, Springer.

North D. (1990): Institutions, Institutional Change and Economic Performance, Cambridge: Cambridge University Press.

Nurse K. (2006): Culture as the Fourth Pillar of Sustainable Development; Commonwealth Secretariat: London, UK.

OECD (2001): Environmental indicators for agriculture. Volume 3: Methods and Results. OECD, Paris.

Raman, S. (2006). Agricultural Sustainability. Principles, Processes and Prospect., New York: The Haworth Press Inc.

RMIT University (2017): The four pillars of sustainability. RMIT University https://www.futurelearn.com/courses/sustainable-business/1/steps/157438

Sarov A. (2019): Assessment of Governance Sustainability of Agricultural Farms in Bulgaria (Оценка на управлнеческата устойчивост на земеделските стопанства в България), Avangard Prima.

Simberova I., A. Kocmanova, P. Nemecek (2012): Corporate Governance Performance Measurement - Key Performance Indicators, Economics and Management, Vol 17, No 4, http://158.129.0.15/index.php/Ekv/article/view/3033/0

Scobie S. and O. Young (2018): Integrating Governance into the Sustainable Development Goals, Post2015, UNU-IAS, Policy Brief 3.

Sauvenier X., J. Valekx, N. Van Cauwenbergh, E. Wauters, H.Bachev. K.Biala, C. Bielders, V. Brouckaert, V. Garcia-Cidad, S. Goyens, M.Hermy, E. Mathijs, B.Muys, M.Vanclooster. and A.Peeters (2005): Framework for Assessing Sustainability Levels in Belgium Agricultural Systems - SAFE, Belgium Science Policy, Brussels.

Singh R., H.Murty, S. Gupta, A.Dikshit (2009): An overview of sustainability assessment methodologies, Ecological indicators, 9, 189-212.

Spangenberg J., Pfahl S. Deller K. (2002): Towards indicators for institutional sustainability: Lessons from an analysis of Agenda 21. Ecological Indicators, 2, 61-77.

Terziev D., D. Radeva, \& Y. Kazakova (2018): A new look on agricultural sustainability and food safety: Economic viability, in H. BACHEV, S. CHE, S. YANCHEVA (Editors) Agrarian and Rural Revitalisation Issues in China and Bulgaria, KSP Books, 231-242.

UCLG (2014): Culture: Fourth Pillar of Sustainable Development, United Cities and Local Governments, Barcelona.

VanLoon G., S. Patil, and L.Hugar (2005): Agricultural Sustainability: Strategies for Assessment. London: SAGE Publications.

UN (2015): The Sustainable Development Goals (SDGs), United Nation.

Zvyatkova D. and A. Sarov (2018): Process of Transfer of Family Farms for Sustainability of Agricultural Cooperatives, in "Role of Family Business for Sustainable Rural Development, Agrarian University, 61 (2), 125-134.

Williamson, O. (1996). The Mechanisms of Governance. New York: Oxford University Press.'

Башев X. (1997). Структура за организация на аграрните транзакции в трансформиращата се икономика, Икономика и управление на селското стопанство, 1-15.

Башев X. (2020). Дигитализация на селското стопанство и райони в България, Икономика и управление на селското стопанство, бр. 2, 3-24. 
Башев Х., М Михайлова (2019). Състояние и развитие на аграрната научноизследователска и развойна дейност в България, Икономика и управление на селското стопанство, бр 3, 322.

Башев Х., М Михайлова (2019).Състояние и развитие на системата за обучение и съвети в селското стопанство на България, Икономика и управление на селското стопанство, бр $3,21-41$.

Иванов Б., Р. Попов, Х. Башев, Н. Котева, Н. Маламова, М. Чопева, К. Тодорова, И. Начева, Д. Митова (2020): Анализ на състоянието на селското стопанство и ХВП, ИАИ. 